\title{
Iron(II) promoted direct synthesis of dibenzo[b,e]oxepin-11(6H)-one derivatives with biological activity. A short synthesis of doxepin
}

\author{
Jimena Scoccia, ${ }^{\mathrm{a}}$ M. Julia Castro, ${ }^{\mathrm{a}, \mathrm{b}}$ M. Belén Faraoni, ${ }^{\mathrm{a}}$ Cecilia Bouzat, ${ }^{\mathrm{b}}$ Víctor S. Martín, ${ }^{\mathrm{c}}$ Darío C. \\ Gerbino, ${ }^{\mathrm{a}, *}$
}

${ }^{a}$ INQUISUR, Departamento de Química, Universidad Nacional del Sur (UNS)-CONICET, Avenida Alem 1253, 8000 Bahía Blanca, Argentina.

${ }^{b}$ INIBIBB, Departamento de Biología, Bioquímica y Farmacia, Universidad Nacional del Sur (UNS)-CONICET, Camino La Carrindanga km 7, 8000 Bahía Blanca, Argentina.

${ }^{c}$ IUBO, Departamento de Química Orgánica, Universidad de La Laguna, C/Astrofísico Francisco Sánchez 2, 38206 La Laguna, Tenerife, Spain.

\section{ARTICLE INFO}

Article history:

Received

Received in revised form

Accepted

Available online

\section{Keywords:}

Synthetic methodology

Dibenzo[b,e]oxepin-11(6H)-ones

Intramolecular acylation,

Doxepin,

Anthelmintic activity.

\section{ABSTRACT}

\begin{abstract}
A novel and efficient synthesis of dibenzo[b,e]oxepin-11(6H)-ones by direct intramolecular ortho-acylation from readily available 2-(phenoxymethyl)benzoic acids was developed. The method takes advantage of a newly developed cooperative system consisting of sustainable $\mathrm{FeCl}_{2}$ and $\mathrm{Cl}_{2} \mathrm{CHOCH}_{3}$ as the key components. This methodology is compatible with a wide variety of functional groups in good to excellent yields and high regioselectivity. The synthetic application of new protocol was extended to the synthesis of known tricyclic drug doxepin as well as a small library of oxepin based derivatives. For the first time, the obtained dibenzo[b,e]oxepinone derivatives were evaluated for their biological activities on the freeliving nematode Caenorhabditis elegans as an effective and cost-efficient model system for anthelmintic discovery.
\end{abstract}

2017 Elsevier Ltd. All rights reserved.

\section{Introduction}

Helminthiasis, also known as worm infection, is a serious problem worldwide resulting in high human morbidity and enormous economic losses in livestock, ${ }^{1}$ especially in tropical and sub-tropical countries. Anthelmintic drugs are used for the control of parasitic infections caused by helminths.. With the increasing incidence of drug resistance and the high cost of existing pharmacological agents, the search for new antiparasitic drugs of synthetic origin is imperative. ${ }^{2}$ Caenorhabditis elegans is a free-living nematode naturally found in soils of temperate climate, which has become a model organism for parasitic nematode research. It is also an excellent system for the screening of compounds with potential anthelmintic activity, because it is inexpensive, readily available, and easy to work. ${ }^{3}$ In addition, $C$. elegans has extensively used to investigate nematode behavior, locomotion, reproduction and death. ${ }^{4}$

Natural products play an important role in drug development, particularly in antineoplasic, antibiotics and antiparasitic drugs. ${ }^{5}$ Their structural diversity is a source of inspiration for drug discovery and the preparation of analogs as simplified, synthetically more accessible and stable models are broadly described in the literature. ${ }^{6}$ In this context, the tricyclic dibenzo[b,e]oxepin-11(6H)-one scaffold also known as "doxepinone", emerges as an interesting synthetic target. In this respect, a large number of compounds having this privileged structure present relevant biological activities, such as antidepressant, anxiolytic, anticholinergic, antihistaminic, ${ }^{7}$ antipsychotic, ${ }^{8}$ analgesic, antipyretic, anti-inflammatory ${ }^{9}$ and antitumor drugs (Fig 1). ${ }^{10}$ The dibenzo[b,e]oxepin-11(6H)-one motif containing natural products, such as chaetones I and II, showed remarkable cytotoxic and antimicrobial activities. ${ }^{11}$ Interestingly, chaetone II also exhibited antitumor activity against gastric cancer cells BGC $823 .^{12}$ Moreover, the metabolite pestalachloride $\mathrm{B}$ displayed significant antifungal activities against different plant pathogens. ${ }^{13}$ Dibenzo[b,e]oxepinones, isoxepac and skepinone-type of synthetic origin were identified as potential therapeutic agents for the treatment of inflammatory diseases, such as rheumatoid arthritis (RA), psoriasis, and Crohn's disease. ${ }^{14}$ In addition, these pharmacophores units are very important in medicinal chemistry due to their proved therapeutic properties.

The biological versatility exhibited by dibenzo[b,e]oxepinones and their congeners makes them very attractive targets for synthetic chemists.

\footnotetext{
* Corresponding author. Tel.: +54-291-459-5101; fax: +54-291-459-5187; e-mail: dgerbino@ uns.edu.ar
} 

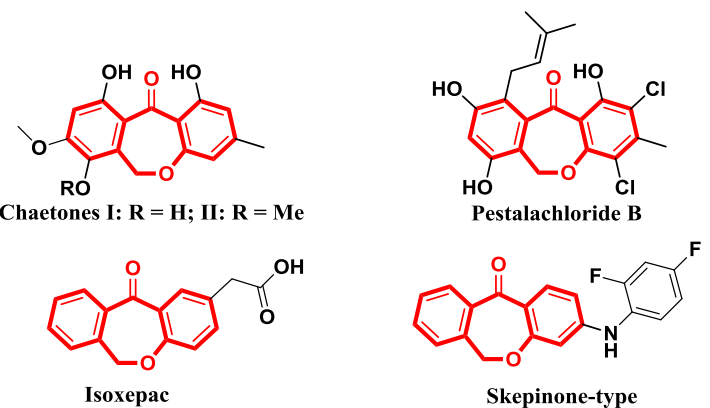

Figure 1. Representative structures of dibenzo[b,e]oxepin$11(6 \mathrm{H})$-ones of biological interest.

Accordingly, the development of efficient methodologies for the construction of dibenzo[b,e]oxepin-11(6H)-one unit has represented a considerable synthetic challenge in the field of organic synthesis. Even though the synthesis of this framework represents a growing field due to the requirements of medicinal chemistry researches, a limited number of approaches for their synthesis has been developed to date. ${ }^{15}$ Among them, the two most common approaches for the synthesis of dibenzo[b,e]oxepinones are: (a) intramolecular C-O bond formation via Williamson ether synthesis $^{16}$ and (b) cyclodehydration or intramolecular Friedel-Crafts acylation reaction of intermediates with a preformed aryl benzyl ether bond. ${ }^{17}$ However, they often suffer from a variety of disadvantages, such as poor yields, severe side reactions, high reaction temperature, prolonged reaction time, requirement of expensive reagents, low tolerance of functional groups ${ }^{15 a, 18}$ and poor regioselectivity. Similarly, another protocol under much milder reaction in the presence of trifluoroacetic anhydride has been developed. ${ }^{19}$ More recently, a new Parham cyclization methodology has been developed for the preparation of diaryl fused oxepinones. This strategy involves the generation of functionalized aryllithiums by bromine-lithium exchange, followed by intramolecular cyclization onto an electrophilic nitrile functional group. ${ }^{20}$

Doxepin is a dibenzo[b,e]oxepine tricyclic with a tertiary amine chemical structure, which is marketed as a mixture of geometric isomers in a ratio of $Z: E=15: 85$. It acts by inhibiting the reuptake of serotonin and norepinephrine at chemical synapses. Its primary use is in the treatment of depression ${ }^{21}$ and it is also occasionally used in treating anxiety disorders and insomnia. As result of their therapeutic importance, doxepin and its congeners are interesting targets for chemical synthesis. Surprisingly, we found few precedents in the scientific literature of the total synthesis of this drug. ${ }^{22}$

Herein, we describe the development of a novel and efficient synthetic strategy for the generation of a small library of dibenzo[b,e]oxepinones by direct intramolecular acylation of 2(phenoxymethyl)benzoic acids by using $\mathrm{FeCl}_{2}$ and $\mathrm{Cl}_{2} \mathrm{CHOCH}_{3}$. To the best of our knowledge, this is the first report of the construction of seven membered oxygen heterocycles employing iron (II) and dichloromethyl methyl ether as cooperative system under mild and simple conditions. The interest and utility of our methodology was successfully applied as a key transformation in the synthesis of tricyclic drug doxepin.

Based on our experience in the biological evaluation of antiparasitic agents ${ }^{23}$ and for the purpose of expanding the spectrum of pharmacological action of dibenzo[b,e]oxepin$11(6 \mathrm{H})$-one scaffold, we decided to test all synthesized dibenzo[b,e]oxepinones derivatives for their anthelmintic activities using as the experimental model the nematode $C$. elegans.

\section{Results and Discussion}

\subsection{Chemistry}

In recent studies, Kong-Wang and co-workers ${ }^{24}$ established an interesting intramolecular acylation of benzyl esters by using the combined system of $\mathrm{FeCl}_{3}$ with $\mathrm{Cl}_{2} \mathrm{CHOCH}_{3}$. This novel reactive system offered an efficient approach to the privileged structure xanthone, ${ }^{25}$ which is structurally closely related to our target dibenzo[b,e]oxepin-11(6H)-one. However, this protocol is subjected to some limitations, such as non-availability of starting materials and low tolerance of electron-withdrawing functional groups. Inspired by this work, and in order to develop an operationally simple synthesis of the diaryl fused oxepin-11(6H)one core, we decided to study the course of the direct intramolecular acylation of readily available 2(phenoxymethyl)benzoic acids by using different Lewis acids and dichloromethyl methyl ether (DCME). The strategic concept of our synthesis is summarized in Scheme 1.

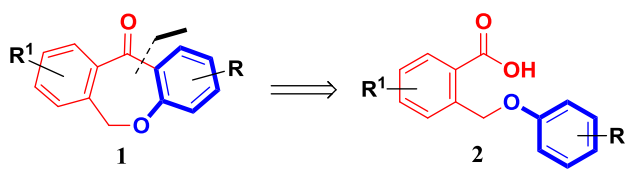

Scheme 1. Retrosynthetic analysis for dibenzo[b,e]oxepin$11(6 \mathrm{H})$-one framework.

The required starting materials for the synthesis of dibenzo[b,e]oxepinones type $\mathbf{1}$ can easily be obtained by treating substituted phthalide I with different sodium phenoxides derivatives II in DMF by modifications to known procedures (see ESI for experimental details). ${ }^{15 \mathrm{a} f}$ An alternative synthetic route to access the substrates type $\mathbf{2}$ involves a Williamson synthesis between methyl 2-(bromomethyl)benzoate derivatives III and substituted phenoxides II followed by acid hydrolysis (Scheme 2).

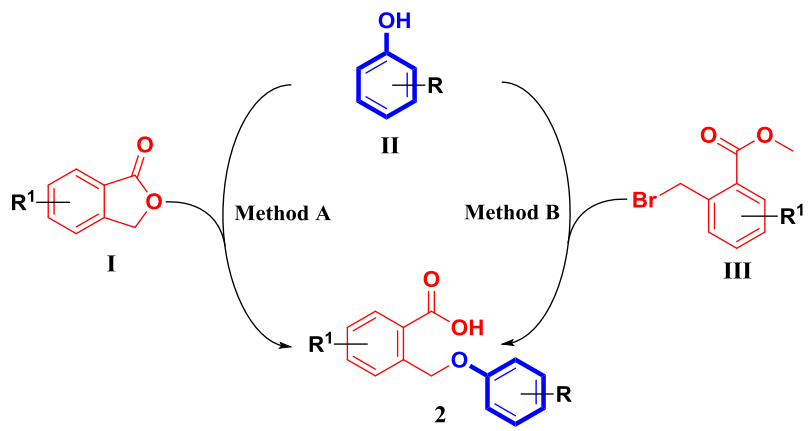

Scheme 2. Preparation of 2-(phenoxymethyl)benzoic acids 2. Method A (2a-2h): NaH (1.5 equiv), DMF, reflux, $24 \mathrm{~h}$; then $1 \mathrm{~N}$ $\mathrm{NaOH}, 1 \mathrm{M} \mathrm{HCl}$; Method B (2i-2l): $\mathrm{K}_{3} \mathrm{PO}_{4}$ (2 equiv), toluene, reflux, $5 \mathrm{~h}$; then $\mathrm{KOH}$, methanol, reflux.

We started our study by choosing 2-((3methoxyphenoxy)methyl)benzoic acid (2c) as model substrate to optimize the reaction conditions. These results are shown in Table 1.

Because of our active interest and experience in the area of green catalysis, ${ }^{25 b}$ we first focused our research on the direct intramolecular acylation of $\mathbf{2} \mathbf{c}$ in the presence of environmentally friendly $\mathrm{FeCl}_{3}$ and DCME, following the protocol reported by Kong-Wang and co-workers. ${ }^{24}$ It was observed that the reaction did not initiate at room temperature or even heating at reflux by using the cooperative system $\mathrm{FeCl}_{3}$ with $\mathrm{DCME}$ in the presence of dichloromethane as solvent (Table 1, entries 1 and 2). On the other hand, $\mathrm{FeBr}_{3}$ was also ineffective in attending this reaction under similar conditions (Table 1, entry 3). Unfortunately, 
increasing the loading of catalyst to 1 equivalent was ineffective for the present transformation, recovering the starting material 2c (Table 1, entry 4). Moreover, when the amount of DCME was increased to 1.5 equivalents for $24 \mathrm{~h}$, only the substrate $\mathbf{2 c}$ was detected in the crude reaction (Table 1 , entry 5). However, to our surprise the reaction was achieved in absence of $\mathrm{FeCl}_{3}$ by using 1 equivalent of DCME albeit with a poor yield of only 20\% (Table 1 , entry 6). Further increasing the amount of DCME did not improve the yield of desired dibenzo[b,e]oxepin-11(6H)-one (Table 1, entry 7).

Table 1. Optimization of the reaction conditions. ${ }^{a}$
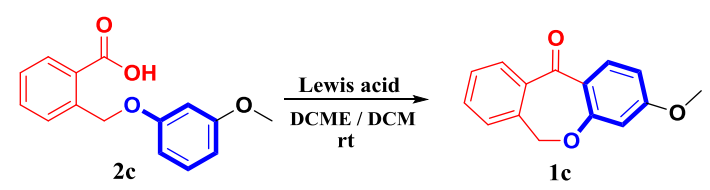

\begin{tabular}{ccccc}
\hline Entry & $\begin{array}{c}\text { Lewis acid } \\
\text { (equiv) }\end{array}$ & $\begin{array}{c}\text { DCME } \\
\text { (equiv) }\end{array}$ & $\begin{array}{c}\text { Time } \\
\text { (h) }\end{array}$ & $\begin{array}{c}\text { Yield } \\
(\boldsymbol{\%})^{\mathrm{c}}\end{array}$ \\
\hline 1 & $\mathrm{FeCl}_{3}(0.6)$ & 1.0 & 24 & $\mathrm{NR}^{\mathrm{d}}$ \\
2 & $\mathrm{FeCl}_{3}(0.6)$ & 1.0 & $24^{\mathrm{e}}$ & $\mathrm{NR}^{\mathrm{d}}$ \\
3 & $\mathrm{FeBr}_{3}(0.6)$ & 1.0 & 24 & $\mathrm{NR}^{\mathrm{d}}$ \\
4 & $\mathrm{FeCl}_{3}(1.0)$ & 1.0 & 24 & $\mathrm{NR}^{\mathrm{d}}$ \\
5 & $\mathrm{FeCl}_{3}(0.6)$ & 1.5 & 24 & $\mathrm{NR}^{\mathrm{d}}$ \\
6 & -- & 1.0 & 24 & 20 \\
7 & -- & 1.5 & 24 & 18 \\
8 & $\mathrm{SnCl}_{4}(0.6)$ & 1.0 & 24 & $\mathrm{NR}^{\mathrm{d}}$ \\
9 & $\mathrm{AlCl}_{3}(0.6)$ & 1.0 & 24 & 10 \\
10 & $\mathrm{CuCl}_{2}(0.6)$ & 1.0 & 3 & 42 \\
11 & $\mathrm{SnCl}_{2}(0.6)$ & 1.0 & 2 & 52 \\
12 & $\mathrm{MgCl}_{2}(0.6)$ & 1.0 & 24 & $\mathrm{NR}^{\mathrm{d}}$ \\
13 & $\mathrm{ZnCl}_{2}(0.6)$ & 1.0 & 2 & 80 \\
14 & $\mathbf{F e C l}_{2}(\mathbf{0 . 6})$ & $\mathbf{1 . 0}$ & $\mathbf{2}$ & $\mathbf{9 0}$ \\
15 & $\mathrm{FeCl}_{2}(0.6)$ & -- & 24 & $\mathrm{NR}^{\mathrm{d}}$ \\
16 & $\mathrm{FeCl}_{2}(0.6)$ & 1.5 & 5 & 90 \\
17 & $\mathrm{FeCl}_{2}(0.6)$ & 0.5 & 5 & 43 \\
18 & $\mathrm{FeCl}_{2}(0.4)$ & 1.0 & 5 & 40 \\
19 & $\mathrm{FeCl}_{2}(0.8)$ & 1.0 & 2 & 80 \\
20 & $\mathrm{FeCl}_{2}(0.6)$ & 1.0 & $24^{\mathrm{f}}$ & 69 \\
21 & $\mathrm{FeCl}_{2}(0.6)$ & 1.0 & $24^{\mathrm{g}}$ & 74 \\
\hline $\mathrm{Stan}$ & & 5 & \\
\hline
\end{tabular}

a Standard reactions conditions: substrate $2 \mathrm{2c}\left(\begin{array}{lll}1 & \mathrm{mmol}\end{array}\right)$, dichloromethyl methyl ether (DCME), in dichloromethane $(0.1 \mathrm{M})$ at room temperature under argon. ${ }^{b}$ Time reaction monitored by TLC and GC-MS. ${ }^{c}$ Quantified by GC analysis using internal standard method. ${ }^{\mathrm{d}}$ NR: no reaction. ${ }^{\mathrm{e}}$ Reaction was conducted in DCM at reflux. ${ }^{\mathrm{f}}$ Reaction was carried out in toluene at room temperature. ${ }^{\mathrm{g}}$ Reaction was carried out in 1,2-dichloroethane (DCE) at room temperature.

Based on the above studies, we decided carry out a systematic screening of the reaction conditions by treating the model substrate 2c with various Lewis acid ${ }^{26}$ in the presence of DCME in dichloromethane at room temperature (Table 1). As shown in the Table, we found that $\mathrm{FeCl}_{2}$ and $\mathrm{ZnCl}_{2}$ led to the best results (Table 1, entries 13 and 14) while other commercially available catalysts including $\mathrm{SnCl}_{4}, \mathrm{AlCl}_{3}, \mathrm{CuCl}_{2}, \mathrm{SnCl}_{2}$ and $\mathrm{MgCl}_{2}$ showed less or no efficiency in terms of chemical yields (Table 1 , entries 8-12). Taking into account the results summarized in Table 1, we choose the Lewis acid $\mathrm{FeCl}_{2}$ for being the most efficient catalyst for the desired transformation. Control experiments were performed to prove the necessity of the coexistence of the catalyst $\mathrm{FeCl}_{2}$ and the agent $\mathrm{Cl}_{2} \mathrm{CHOCH}_{3}$. The experimental results showed that the presence of DCME is crucial for the success of the reaction (entry 15). When the amount of DCME was decreased to 0.5 equivalent, a pronounced decrease was observed (i.e., 43\%, Table 1, entry 17). Both the increase and the decrease of catalyst loading were not effective in improving yields of the desired transformation (Table 1, entries 18 and 19). Further increase of DCME from 1.0 to 1.5 equivalent did not improve the yield of 1c (Table 1, entry 16). From the loading of iron (II) chloride, it could be shown that 0.6 equivalent of $\mathrm{FeCl}_{2}$ was the optimal choice (Table 1, entry 14 regarding entries 18 and 19). On other hand, the screening of the reaction solvent demonstrated that dichloromethane (Table 1, entry 14) was superior in comparison to toluene and 1,2-dichloroethane (Table 1, entries 20 and 21). These combined studies demonstrated that 0.6 equivalent of environmentally friendly $\mathrm{FeCl}_{2}$ by using 1.0 equivalent of DCME in the presence of dichloromethane at room temperature exhibited the highest efficiency for the direct intramolecular acylation from $\mathbf{2 c}$.

In order to extend the scope and the general efficiency of our methodology, we also applied this protocol to the synthesis of twelve functionalized dibenzo[b,e]oxepinones $\mathbf{1 a - 1 1}$ under the optimized conditions (Table 2).

Table 2. Scope for the synthesis of functionalized dibenzo[b,e]oxepin-11(6H)ones. ${ }^{\mathrm{a}}$

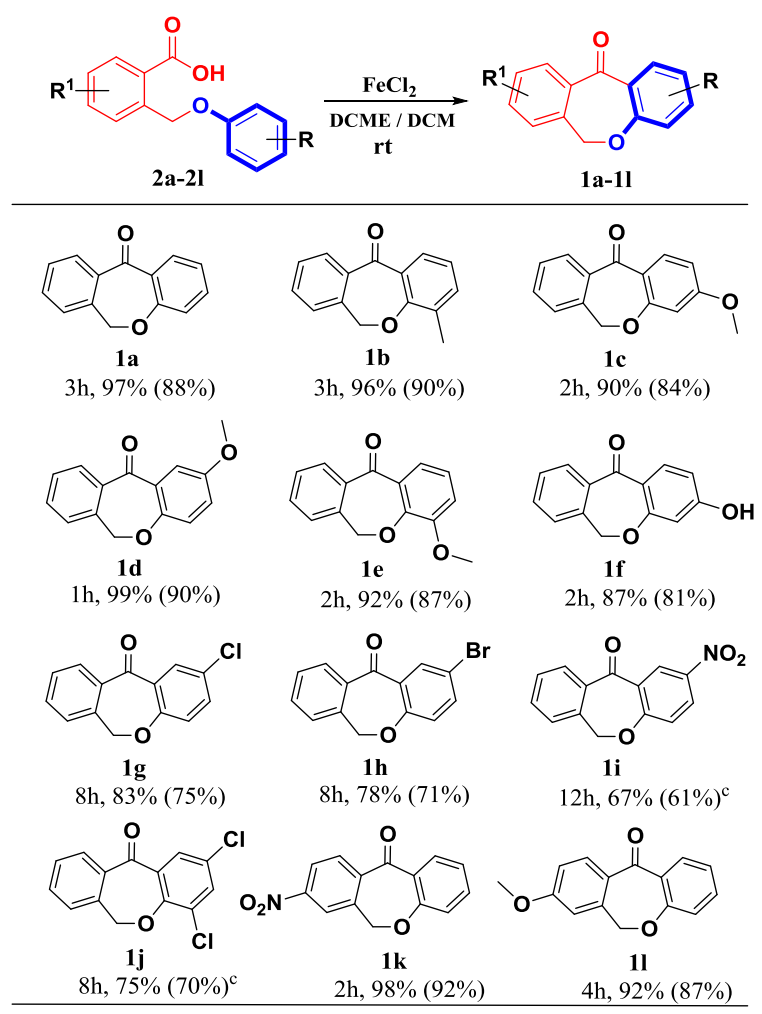

${ }^{\text {a }}$ Reaction conditions: substrate 2 ( $\left.1 \mathrm{mmol}\right), \mathrm{FeCl}_{2}(0.6$ equiv), DCME (1 equiv), in dichloromethane $(0.1 \mathrm{M})$ at room temperature under argon. Time reaction monitored by TLC and GC-MS. Quantified by GC analysis using internal standard method. Isolated yield after purification (in parentheses). ${ }^{\mathrm{c}}$ Reaction was conducted in 1,2-dichloroethane (DCE) at reflux in the presence of $\mathrm{FeCl}_{2}$ (1 equiv). 
The results illustrated in Table 2 indicate that the present methodology is compatible with the presence of a wide variety of functional groups in the substrates $\mathbf{2}$, including nitro, bromo, chlorine, alkoxy, alkyl, and a free phenolic hydroxyl group, affording a set of substituted dibenzo[b,e]oxepinones $\mathbf{1 a}-\mathbf{1 l}$ in very good to excellent yields. Gratifyingly, treatment of compound $\mathbf{2 k}$ bearing a strong electron-withdrawing group nitro led to $\mathbf{1 k}$ in high yield. The acylation reaction of the starting materials with electron-donating substituents (2b-2f, and 2l) proceeded under the optimized reaction conditions in very good yields (1)-1f and 11). It should be noted, that by using our protocol allowed the synthesis of tricyclic fused rings starting from 2-(phenoxymethyl)benzoic acids $\mathbf{2}$ bearing electron-withdrawing groups $\mathbf{1 g - 1 \mathbf { k }}$, thus overcoming one of the limitations reported by other authors. ${ }^{15 a, f}$ The oxepinone 1i was formed very slowly in the presence of only $\mathrm{FeCl}_{2}(0.6$ equiv), but the reaction yield was improved to $61 \%$ by an increase in catalyst loading (1 equiv) in the presence of 1,2dichloroethane at reflux. In this case, we think that the need to use 1 equivalent of Lewis acid could be related to that part of equivalent is preferably coordinated with the strong metadirector $\mathrm{NO}_{2}$, leaving to the rest available to react with the corresponding substrate, thus generating carbocation, which promotes intramolecular acylation desired. ${ }^{27}$ To our satisfaction, treatment of compound $\mathbf{2} \mathbf{j}$ bearing two electronwithdrawing groups chlorine, afforded $\mathbf{1} \mathbf{j}$ in good yield. The intramolecular acylation showed total para regioselectivity for the substrates containing a meta-substituent in the phenolic ring (1c and 1f). The observed selectivity could be attributed in terms of a higher thermodynamic stability of the para regioisomer with respect to the ortho isomer. This reasoning would be in line with the fact that the acylation reaction could occur at the less sterically hindered ortho- $\mathrm{C}-\mathrm{H}$ bond of the 2(phenoxymethyl)benzoic acid derivatives used as precursors (2c and 2f).

A comparison of our procedure with the typically employed strategies to perform this kind of ortho-acylation reaction revealed that the target dibenzo[b,e]oxepin-11(6H)-one is obtained in much more efficient in terms of yields when employing our simple and practical protocol (Table 3). In general, the existing methodologies employ drastic conditions such as phosphorus pentoxide-ethanol ${ }^{28 a, 9 b}$ (Table 3, entry 1), polyphosphoric acid ${ }^{9 \mathrm{~b}}$ (Table 3, entry 2), trifluoroacetic anhydride ${ }^{29}$ with or without $\mathrm{BF}_{3} \cdot \mathrm{Et}_{2} \mathrm{O}$ (Table 3, entry 4). However, our protocol substantially differs from these latter (Table 3, entry 5) in avoiding the use of large amounts of toxic acid chloride like thionyl chloride ${ }^{9 b}$ (Table 3, entry 3), long reaction times, high temperatures and the generation of significant quantities of waste upon quenching of the reaction mixtures, that adversely impact their suitability for a potential scalability. In addition, our strategy uses simple precursors without need of previous activation. On the other hand, the present process allows a greater tolerance of functional groups in both rings of the starting material and greater operational simplicity than the methodologies reported to date.

Under these mild conditions, no acylation side-products were detected arising from cooperative system $\mathrm{FeCl}_{2}$ and DCME, which is not typically employed in Friedel-Crafts acylations. The work-up and isolation of crude product consisted of operational simplicity by simple washing with water followed by extraction with DCM and subsequent treatment with aqueous saturated $\mathrm{NaHCO}_{3}$, then the combined organic layers were dried over anhydrous $\mathrm{Na}_{2} \mathrm{SO}_{4}$ and the solvent was removed under reduced pressure. Finally, the desired product was purified by column chromatography using silica gel 60 or recrystallized from ethanol. The structures of all dibenzo[b,e]oxepinones 1a-1l were confirmed on the basis of their spectroscopic data, as provided in the Experimental section.

Having proved the efficiency and reliability of our methodology to access the dibenzo[b,e]oxepin-11(6H)-one framework, we sought to extend the present protocol to the synthesis of the known drug doxepin.

The classic approach for the synthesis of doxepin uses the ethyl ester of 2-phenoxymethyl benzoic acid as starting material, which is easily synthesized by reacting ethyl 2bromomethylbenzoate with phenol in the presence of a base. ${ }^{22 \mathrm{~d}}$ The resulting ester is hydrolyzed into 2-phenoxymethylbenzoic acid, which is cyclized to dibenzo[b,e]oxepin-11(6H)-one (1a) by trifluoroacetic acid anhydride. Finally, the target molecule is obtained by reacting 1a with 3-dimethylaminopropylmagnesium bromide and the subsequent dehydration of the resulting tertiary alcohol by hydrochloric acid. This strategy involved five steps of synthesis with an overall yield of $26 \%$. A more recent stereoselective synthesis of doxepin was communicated by Luo et al. ${ }^{22 f}$ Thus, the linear synthesis of doxepin required of six steps and proceeded with an overall yield of $7 \%$ starting from 2[(trimethylsilyl)ethynyl]benzyl bromide.

Simplified retrosynthetic analysis of doxepin $\mathbf{3}$ is summarized in Scheme 3. As a key consideration, we proceed to assemble the dibenzo[b,e]oxepin-11(6H)-one (1a) scaffold through a direct intramolecular acylation from 2-(phenoxymethyl)benzoic (2a) acid mediated by eco-friendly $\mathrm{FeCl}_{2}$ and DCME.

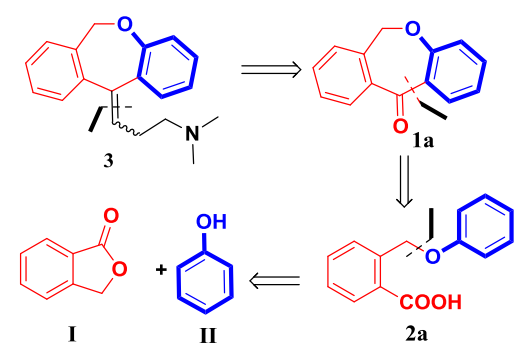

Scheme 3. Retrosynthetic analysis to access the doxepin 3.

The target 3-(dibenzo[b,e]oxepin-11(6H)-ylidene)- $N, N$ dimethyl propan-1-amine (3) was synthesized in three stages. In the first stage, the 2-(phenoxymethyl) benzoic acid (2a) was

Table 3. Comparison of the current methodology with some protocols previously reported for the synthesis of dibenzo[b,e]oxepin$11(6 \mathrm{H})$ ones.

\begin{tabular}{|c|c|c|c|c|}
\hline Entry & Reaction conditions & Time (h) & Yield $(\%)^{\mathrm{a}}$ & Ref \\
\hline 1 & $\mathrm{P}_{2} \mathrm{O}_{5}$ (exc.) / EtOH / sulfolane, reflux & $5-12$ & $20-64$ & $28 \mathrm{a}$ \\
\hline 2 & polyphosphoric acid (exc.), $100^{\circ} \mathrm{C}$ & $3-12$ & $38-53$ & $9 b$ \\
\hline 3 & $\mathrm{SOCl}_{2}$ (exc.) / DCE / $\mathrm{AlCl}_{3}$ (1 equiv), reflux & $2-18$ & $40-79$ & $15 \mathrm{a}$ \\
\hline 4 & Trifluoroacetic anhydride (2 equiv), DCM, reflux & $4-10$ & $41-86$ & $29 \mathrm{a}$ \\
\hline 5 & $\mathrm{FeCl}_{2}$ (0.6 equiv) / DCME (1 equiv) / DCM, rt & $1-12$ & $61-92$ & Current work \\
\hline
\end{tabular}

${ }^{\mathrm{a}}$ Isolated yield after purification. 
easily prepared by treating the commercial available isobenzofuran-1(3H)-one (I) with sodium phenoxide, which was obtained by reacting phenol (II) with $\mathrm{NaH}$ in the presence of DMF at reflux. The carboxylic acid 2a was precipitated using a mineral acid solution. The key intermediate 1a was cyclized by intramolecular acylation from $\mathbf{2 a}$ by using $\mathrm{FeCl}_{2}$ and dichloromethyl methyl ether (DCME) as cooperative system in the presence of dichloromethane at room temperature. Finally, the target molecule $\mathbf{3}$ was synthesized by reacting 1a with 3dimethylaminopropylmagnesium chloride and the subsequent dehydration of the resulting tertiary alcohol by hydrochloric acid at reflux in good yield (Scheme 4).

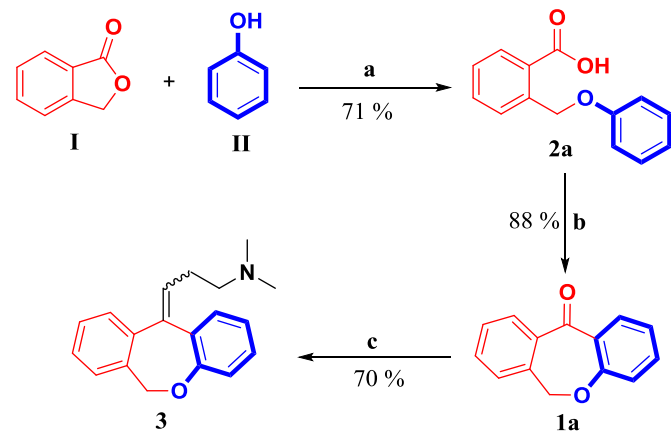

Scheme 4. Total synthesis of doxepin 3. Conditions: a) $\mathrm{NaH}(1.5$ equiv), DMF, reflux, $24 \mathrm{~h}$; then conc. $\mathrm{HCl}$; b) $\mathrm{FeCl}_{2}$ (0.6 equiv), DCME ( 1 equiv), DCM $(0.1 \mathrm{M}), \mathrm{rt}, 3 \mathrm{~h}$; c) 3 -( $N, N$-dimethylamino) propylmagnesium chloride, toluene, $65^{\circ} \mathrm{C}, 2 \mathrm{~h}$; then conc. $\mathrm{HCl}, 1 \mathrm{~h}$, reflux.

The proportion between $(E)$ and $(Z)$-isomers in the crude product was 4 to 1 . The structure elucidation of $\mathbf{3}$ was proved by its GC-MS, ${ }^{1} \mathrm{H}$, and ${ }^{13} \mathrm{C}$ NMR spectra analysis.

It should be noted that the $(E)$-isomer was easily separated by crystallization as maleate salt after treatment of $\mathbf{3}$ with an equivalent amount of maleic acid in dry ethanol.

This synthesis of $\mathbf{3}$ involves only three steps and proceeds with an overall yield of $44 \%$ starting from commercially available phthalide $\mathbf{I}$, thus overcoming the best chemical yields reported by other authors ${ }^{22, \mathrm{f}}$ until now. Notably, most intermediates are crystalline solids and only one of the three steps required chromatographic purification. Thus, the synthesis of $\mathbf{3}$ could be performed on a multigram scale enabling us to also investigate some aspects of the reactivity.

\subsection{Anthelmintic activity}

In a recent study, doxepin structurally related to our target dibenzo[b,e]oxepin-11(6H)-one, have been shown to have anthelmintic activity against the intestinal helminth Ancylostoma ceylanicum third-stage larvae (L3) ${ }^{30}$ In this context, and considering the experience of our group in biological assays associated with this type of activity, added to the fact that there are no contributions in the scientific literature on such biological action, we sought to determine if our synthesized tricyclic scaffolds act as antiparasitic drugs. To this end, we used $C$. elegans as a model of helminthic parasites and measured their rapid effects on $C$. elegans mobility by the thrashing assay method.

The thrashing rate of wild-type worms in M9 buffer (plus 1\% DMSO) was $204 \pm 9.3 / \mathrm{min}$. After a 10 -min incubation period with compounds 1a-1l and doxepin $3(1 \mathrm{mM})$, a slight albeit statistically significant reduction in the thrashing rate was observed (Fig 2).
For these compounds, the thrashing rates varied between 60 $84 \%$ with respect to the control condition. Interestingly, compound 1a produced a much more significant effect on worm mobility, leading to a reduction of $80 \%$ of the thrashes/ min at 1 $\mathrm{mM}$ after a 10-min exposure (Fig 2).

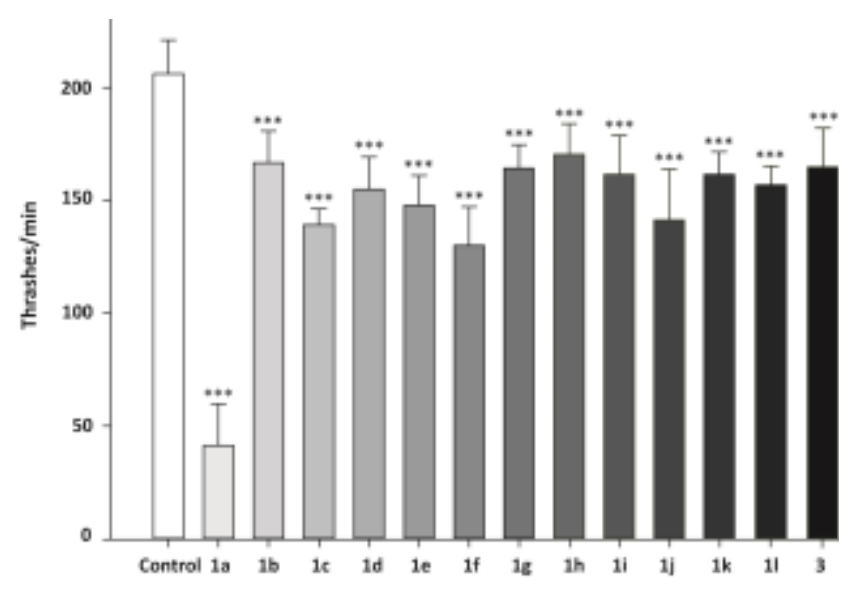

Figure 2. Thrashing rates after $10 \mathrm{~min}$ incubation in M9 solution in the absence (control) or presence of a given compound (1 mM). Assays were performed on three separate days for each drug. Twenty animals were tested in each assay. $* * * \mathrm{P}<0.001$.

When analyzed at a range of concentrations $(30 \mu \mathrm{M}$ to 1.5 $\mathrm{mM}$ ), compound 1a produced a concentration-dependent decrease of the trashing rate, with an $\mathrm{IC}_{50}$ value of $389 \pm 50 \mu \mathrm{M}$ (Fig 3).

Increasing the incubation period to $20 \mathrm{~min}$ in the presence of 1 $\mathrm{mM}$ compound 1a produced complete paralysis of worms. Thrashing assays are useful to demonstrate short-term and rapid effects of compounds on the high-frequency $C$. elegans locomotion. In these assays, common anthelmintic drugs, such as levamisole, morantel and pyrantel $(1 \mathrm{mM})$, have been shown to affect significantly the thrashing rates after 5-10 $\mathrm{min}$ in M9 solution, leading to a $90 \%$ reduction and producing paralysis of the majority of animals. ${ }^{31}$ Thus, we showed that dibenzo[b,e]oxepin-11(6H)-one 1a produces similar effects to those mediated by widely-used anthelmintic drugs.

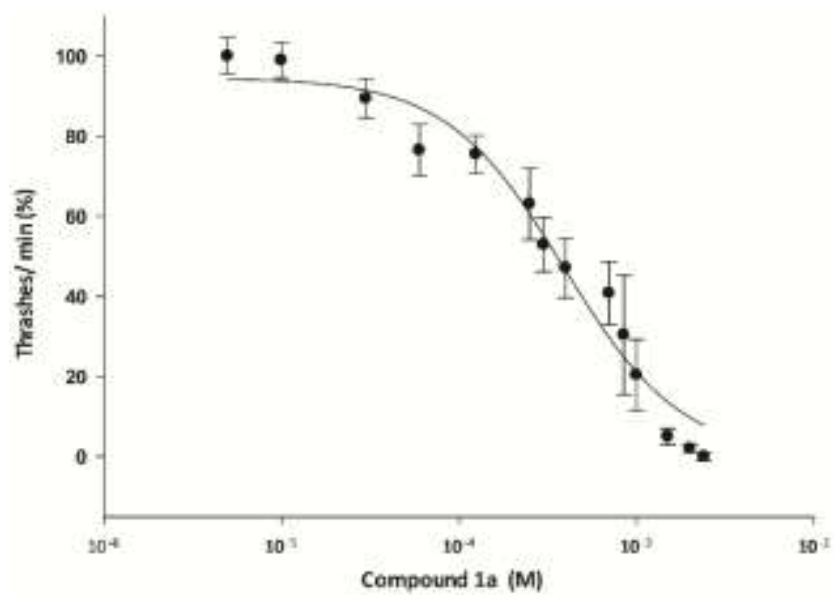

Figure 3. Dose-response curve for dibenzo[b,e]oxepin-11(6H)one 1a. Thrashing rates were plotted as a percentage of the control condition in the absence of the drug. Values are mean percentages \pm SD derived from three trials performed on separate days. All experiments were performed at $20-22{ }^{\circ} \mathrm{C}$. 
Previous reports showed that doxepin 3 produced $60 \%$ death of A. ceylanicum. However, in this work death was evaluated after $72 \mathrm{~h}$ exposure to the drug and, therefore, only long-term effects were considered. ${ }^{30}$ In contrast, our assays evaluate shortterm effects since worms are exposed to the drugs for only 10 min. Under these conditions, doxepin 3 produced a very slight anthelmintic effect on $C$. elegans. A short-term effect as the one observed for compound 1a might be mediated by ion channels, such as ligand-gated ion channels, which are involved in neuromuscular function and worm locomotion. Typical anthelmintics, such as pyrantel, morantel, and levamisole, act by this mechanism. ${ }^{21}$ In general terms, it was observed that the introduction of functionality to the tricyclic ring system 1a was detrimental to biological activity. Interestingly, a marked decrease in activity was observed for doxepin 3, suggesting that the carbonyl group was important for the activity. Thus, the pharmacophore appeared to be the scaffold 1a, which may be considered as a candidate anthelmintic drug. Although levamisole and pyrantel are effective antiparasitic drugs, the increment of drug resistance of nematodes to these anthelmintic drugs as well as to the limited number of available drugs has become a global concern for veterinary and human health. Indeed, the combination of drugs is emerging as a strategy tending to fight against the increase in anthelmintic resistance. Thus, the identification of novel drugs and pharmacological targets is urgently required, which enhances the importance of the anthelmintic action of compound 1a here reported. Thus, future work will focus on the identification of the pharmacological target by which compound 1a exerts its antiparasitic activity. Once this target is known, derivatization of the active compound to increase its potency and efficacy will be rationally planned.

\section{Conclusions}

In the current research, we have developed a new and complementary methodology for the simple construction of dibenzo[b,e]oxepin-11(6H)-ones from readily available 2(phenoxymethyl)benzoic acids by using $\mathrm{FeCl}_{2}$ and $\mathrm{Cl}_{2} \mathrm{CHOCH}_{3}$ as an efficient cooperative system. Unlike other existing standard Friedel-Crafts approaches, our strategy showed an excellent tolerance to diverse substituent groups makes the reaction a fairly general synthesis protocol to diaryl fused oxepin-11(6H)-ones. Due to the modularity, operational simplicity, and reliability it is likely that the method will find future exploitation in the synthesis of compound libraries, and therefore have an impact on to the field of medicinal chemistry. We are currently working on the design of some specific experiments aimed at shed light on the exact reaction mechanism. To probe the general application of our protocol, we elaborated a short and scalable synthesis of tricyclic drug doxepin 3 from commercial available phthalide. The scalability of the process, the simple reaction conditions, and the low cost of the starting materials, make this new total synthesis transferable to the pharmaceutical industry. The synthetic accessibility and significant antiparasitic activity exhibited by dibenzo[b,e]oxepin-11(6H)-one 1 a might be a promising lead in the search for novel anthelmintic drugs. It is noteworthy that this is the first report of anthelmintic activity of this class of oxygenated tricyclic compounds using the free-living nematode Caenorhabditis elegans as an experimental model system. Future studies may be directed to identify its mechanism of action and drug target.

\section{Experimental section}

\subsection{General}

All operations were performed under an argon atmosphere using standard Schlenk techniques. Solvents were dried and distilled in accordance with standard procedure. ${ }^{32}$ Reactions were monitored by thin-layer chromatography on silica gel plates (60F-254) visualized under UV light and/or using 5\% phosphomolybdic acid in ethanol. All ${ }^{1} \mathrm{H}$ and ${ }^{13} \mathrm{C}$ NMR spectra were recorded at room temp. in $\mathrm{CDCl}_{3}, \mathrm{DMSO}-d_{6}$ or Acetone- $d_{6}$ on a Bruker Avance ARX-300 spectrophotometer. Chemical shifts $(\delta)$ are reported in parts per million (ppm) from tetramethylsilane (TMS) using the residual solvent resonance $\left(\mathrm{CDCl}_{3}: 7.26 \mathrm{ppm}\right.$ for ${ }^{1} \mathrm{H} \mathrm{NMR}$ and $77.16 \mathrm{ppm}$ for ${ }^{13} \mathrm{C} \mathrm{NMR}$; DMSO- $d_{6}: 2.50 \mathrm{ppm}$ for ${ }^{1} \mathrm{H}$ NMR and $39.50 \mathrm{ppm}$ for ${ }^{13} \mathrm{C} \mathrm{NMR}$; Acetone- $d_{6}: 2.09$ ppm for ${ }^{1} \mathrm{H}$ NMR, 30.60 and $205.87 \mathrm{ppm}$ for ${ }^{13} \mathrm{C}$ NMR). Multiplicities are abbreviated as follows: $\mathrm{s}=$ singlet, $\mathrm{d}=$ doublet, $\mathrm{t}=$ triplet, $\mathrm{q}=$ quartet, $\mathrm{m}=$ multiplet; brs $=$ broad signal). IR spectra were recorded on a Perkin-Elmer Paragon 1000 FT-IR spectrometer in the ATR mode at room temp. Melting points were determined using a Büchi 510 apparatus and are not corrected. Mass spectra (EI) were obtained at $70 \mathrm{eV}$ on an Agilent CG-78903 instrument equipped with a MS-5977A MSD selective mass detector. The purity of volatile compounds and the chromatographic analyses (GC) were determined with a GC Shimadzu (GC-14B) with a flame ionization detector equipped with a HP-5MS column $(30 \mathrm{~m} \times 0.25 \mathrm{~mm} \times 0.25 \mu \mathrm{m})$ using nitrogen as carrier gas. High resolution mass spectra were recorded on Thermo Fisher LTQ Orbitrap XL, (for EI) and a Finnigen MAT 95 (for ESI). Flash column chromatography was performed using Macherey Nagel MN Kieselgel 60M (0.040$0.063 \mathrm{~mm} / 230-240$ mesh ASTM). All starting materials were of the best available grade (Aldrich, Merck, Acros or TCI) and were used without further purification. (CAUTION) Dichloromethyl methyl ether is a corrosive and acute toxic reagent.

4.2. General procedure for synthesis of 2-(phenoxymethyl) benzoic acids (2a-2l).

\section{Method A (2a-2h).}

Substituted phenol (16 mmol) was added to a stirred suspension of sodium hydride $(24 \mathrm{mmol})$ in anhydrous DMF (20 $\mathrm{mL})$. Upon cessation of dihydrogen evolution, phthalide (15 mmol), dissolved in the minimum amount of benzene (CAUTION) and the mixture heated under reflux for $24 \mathrm{~h}$. The cooled solution was poured into ice water $(50 \mathrm{~mL})$ and acidified with conc. $\mathrm{HCl}$. The formed precipitate was filtered, washed with water and subsequently dissolved in dichloromethane $(50 \mathrm{~mL})$. The organic layer was washed successively with $20 \%$ aq. $\mathrm{Na}_{2} \mathrm{CO}_{3}$ $(3 \times 20 \mathrm{~mL})$ and water $(3 \times 20 \mathrm{~mL})$, and dried over $\mathrm{Na}_{2} \mathrm{SO}_{4}$. The solvent was distilled off to give a solid. The crude product was used in the next step without further purification.

2-(phenoxymethyl)benzoic acid (2a). ${ }^{15 a}$ Isolated yield: $65 \%$ (white solid, $550 \mathrm{mg}, 2.41 \mathrm{mmol}$ ); mp 112-114 ${ }^{\circ} \mathrm{C} ;{ }^{1} \mathrm{H}$ NMR $\left(\mathrm{CDCl}_{3}, 300 \mathrm{MHz}\right) \delta 5.53(\mathrm{~s}, 2 \mathrm{H}), 6.95-7.03(\mathrm{~m}, 3 \mathrm{H}), 7.26-7.34$ $(\mathrm{m}, 2 \mathrm{H}), 7.40-7.45(\mathrm{~m}, 1 \mathrm{H}), 7.63(\mathrm{dt}, J=7.6,1.3 \mathrm{~Hz}, 1 \mathrm{H}), 7.81-$ $7.84(\mathrm{~m}, 1 \mathrm{H}), 8.18(\mathrm{dd}, J=7.9,1.2 \mathrm{~Hz}, 1 \mathrm{H}) .{ }^{13} \mathrm{C} \mathrm{NMR}\left(\mathrm{CDCl}_{3}\right.$, $75 \mathrm{MHz}) \delta 68.2,115.1,121.2,126.4,127.4,127.5,129.7,131.9$, 133.8, 140.9, 158.8, 172.2; IR (KBr) $v\left[\mathrm{~cm}^{-1}\right]=3440,3051,2897$, $1685,1594,1243$. HRMS (EI) $\mathrm{m} / \mathrm{z}=228.0786$ calcd for $\mathrm{C}_{14} \mathrm{H}_{12} \mathrm{O}_{3}$, found 228.0781 .

2-((o-tolyloxy)methyl)benzoic acid (2b) ${ }^{33}$ Isolated yield: 58\% (white solid, $910 \mathrm{mg}, 3.75 \mathrm{mmol}$ ); mp 137-139 ${ }^{\circ} \mathrm{C} ;{ }^{1} \mathrm{H}$ NMR $\left(\mathrm{CDCl}_{3}, 300 \mathrm{MHz}\right) \delta 2.40(\mathrm{~s}, 3 \mathrm{H}), 5.57(\mathrm{~s}, 2 \mathrm{H}), 6.88-6.93(\mathrm{~m}$, $2 \mathrm{H}), 7.15-7.21(\mathrm{~m}, 2 \mathrm{H}), 7.44(\mathrm{t}, J=7.4 \mathrm{~Hz}, 1 \mathrm{H}), 7.66(\mathrm{t}, J=7.4$ 
$\mathrm{Hz}, 1 \mathrm{H}), 7.90(\mathrm{~d}, J=7.7 \mathrm{~Hz}, 1 \mathrm{H}), 8.21(\mathrm{~d}, J=7.7 \mathrm{~Hz}, 1 \mathrm{H}) ;{ }^{13} \mathrm{C}$ $\mathrm{NMR}\left(\mathrm{CDCl}_{3}, 75 \mathrm{MHz}\right) \delta 16.6,68.1,111.7,120.8,126.4,127.0$, $127.1,127.2,127.3,130.9,131.8,133.8,141.3,156.8,172.7$. IR $(\mathrm{KBr}) \vee\left[\mathrm{cm}^{-1}\right]=3438,3058,2898,1696,1595,1240$. HRMS (EI) $\mathrm{m} / \mathrm{z}=242.0943$ calcd for $\mathrm{C}_{15} \mathrm{H}_{14} \mathrm{O}_{3}$, found 242.0948 .

2-((3-methoxyphenoxy)methyl)benzoic acid (2c). Isolated yield: $43 \%$ (light brown solid, $1.67 \mathrm{~g}, 6.47 \mathrm{mmol}$ ); mp 105-107 ${ }^{\circ} \mathrm{C} ;{ }^{1} \mathrm{H}$ NMR $\left(\mathrm{CDCl}_{3}, 300 \mathrm{MHz}\right) \delta 3.71(\mathrm{~s}, 3 \mathrm{H}), 5.47(\mathrm{~s}, 2 \mathrm{H})$, 6.44-6.54 (m, 3H), 7.09-7.18 (m, 3H), 7.34 (t, $J=7.6 \mathrm{~Hz}, 1 \mathrm{H})$, $7.54(\mathrm{t}, J=7.6 \mathrm{~Hz}, 1 \mathrm{H}), 7.73(\mathrm{~d}, J=8.0 \mathrm{~Hz}, 1 \mathrm{H}), 8.10(\mathrm{~d}, J=8.0$ $\mathrm{Hz}, 1 \mathrm{H}) ;{ }^{13} \mathrm{C} \mathrm{NMR}\left(\mathrm{CDCl}_{3}, 75 \mathrm{MHz}\right) \delta 55.4,68.3,101.7,106.7$, $107.3,126.5,127.4,127.5,130.1,131.9,133.8,140.8,160.0$, 161.0, 172.6. IR $(\mathrm{KBr}) \vee\left[\mathrm{cm}^{-1}\right]=3441,3055,2901,1691,1594$, 1234. HRMS (EI) $\mathrm{m} / \mathrm{z}=258.0892$ calcd for $\mathrm{C}_{15} \mathrm{H}_{14} \mathrm{O}_{4}$, found 258.0896 .

2-((4-methoxyphenoxy)methyl)benzoic acid (2d). ${ }^{34}$ Isolated yield: $60 \%$ (white solid, $486 \mathrm{mg}, 1.88 \mathrm{mmol}$ ); mp $163-165{ }^{\circ} \mathrm{C} ;{ }^{1} \mathrm{H}$ NMR $\left(\mathrm{CDCl}_{3}, 300 \mathrm{MHz}\right) \delta 3.72(\mathrm{~s}, 3 \mathrm{H}), 5.46(\mathrm{~s}, 2 \mathrm{H}), 6.85-6.88$ $(\mathrm{m}, 2 \mathrm{H}), 6.93-6.96(\mathrm{~m}, 2 \mathrm{H}), 7.42-7.47(\mathrm{~m}, 1 \mathrm{H}), 7.62(\mathrm{dt}, J=7.5$, $1.4 \mathrm{~Hz}, 1 \mathrm{H}), 7.77(\mathrm{~d}, J=7.8 \mathrm{~Hz}, 1 \mathrm{H}) 8.07(\mathrm{dd}, J=7.8,1.4 \mathrm{~Hz}$, $1 \mathrm{H}) .{ }^{13} \mathrm{C} \mathrm{NMR}\left(\mathrm{CDCl}_{3}, 75 \mathrm{MHz}\right) \delta 55.9,69.4,115.5,116.6$, $128.2,128.4,129.3,131.8,133.3,141.0,153.9,155.1,168.4$. IR $(\mathrm{KBr}) \vee\left[\mathrm{cm}^{-1}\right]=3431,3050,2899,1693,1598,1231$. HRMS (EI) $\mathrm{m} / \mathrm{z}=258.0892$ calcd for $\mathrm{C}_{15} \mathrm{H}_{14} \mathrm{O}_{4}$, found 258.0897.

2-((2-methoxyphenoxy)methyl)benzoic acid (2e). Isolated yield: $54 \%$ (light brown solid, $1.20 \mathrm{~g}, 4.70 \mathrm{mmol}$ ); mp 123-125 ${ }^{\circ} \mathrm{C} ;{ }^{1} \mathrm{H}$ NMR $\left(\mathrm{CDCl}_{3}, 300 \mathrm{MHz}\right) \delta 3.08(\mathrm{~s}, 3 \mathrm{H}), 5.65(\mathrm{~s}, 2 \mathrm{H})$, 6.89-6.95 (m, 4H), 7.38-7.43 (m, 1H), 7.59-7.64 (m, 1H), 7.86 (d, $J=7.9 \mathrm{~Hz}, 1 \mathrm{H}), 8.16-8.19(\mathrm{~m}, 1 \mathrm{H}) ;{ }^{13} \mathrm{C} \mathrm{NMR}\left(\mathrm{CDCl}_{3}, 75 \mathrm{MHz}\right)$ $\delta 55.1,69.3,112.0,114.1,121.0,121.6,126.3,127.3,127.4$, $131.8,133.9,141.0,148.2,149.7,172.6 . \mathrm{IR}(\mathrm{KBr}) \vee\left[\mathrm{cm}^{-1}\right]=$ 3440, 3052, 2901, 1692, 1595, 1230. HRMS (EI) $\mathrm{m} / \mathrm{z}=$ 258.0892 calcd for $\mathrm{C}_{15} \mathrm{H}_{14} \mathrm{O}_{4}$, found 258.0896.

2-((3-hydroxyphenoxy)methyl)benzoic acid (2f). ${ }^{35}$ Isolated yield: 53\% (light brown solid, $34 \mathrm{mg}, 1.39 \mathrm{mmol}$ ); mp 113-115 ${ }^{\circ} \mathrm{C} ;{ }^{1} \mathrm{H}$ NMR (DMSO- $\left.d_{6}, 300 \mathrm{MHz}\right) \delta 5.34(\mathrm{~s}, 2 \mathrm{H}), 6.43-6.34(\mathrm{~m}$, $3 \mathrm{H}), 7.05-7.10(\mathrm{~m}, 1 \mathrm{H}), 7.42(\mathrm{dt}, J=7.5,2.0 \mathrm{~Hz}, 1 \mathrm{H}), 7.62-7.57$ $(\mathrm{m}, 2 \mathrm{H}), 7.89-7.91(\mathrm{~m}, 1 \mathrm{H}), 7.2$ (brs, $1 \mathrm{H}), 12.9$ (brs, $1 \mathrm{H}) ;{ }^{13} \mathrm{C}$ NMR (DMSO- $\left.d_{6}, 75 \mathrm{MHz}\right) \delta 62.2,102.2,108.1,110.1,126.3$, $127.3,130.5,131.0,131.8,139.9,157.1,160.3,172.7 . \mathrm{IR}(\mathrm{KBr}) \mathrm{v}$ $\left[\mathrm{cm}^{-1}\right]=3441,3055,2900,1695,1598,1235,1230$. HRMS (EI) $\mathrm{m} / \mathrm{z}=244.0736$ calcd for $\mathrm{C}_{14} \mathrm{H}_{12} \mathrm{O}_{4}$, found 244.0740.

2-((4-chlorophenoxy)methyl)benzoic acid (2g). ${ }^{15 \mathrm{a}}$ Isolated yield: 54\% (light brown solid, $86 \mathrm{mg}, 3.29 \mathrm{mmol}$ ); mp 160-162 ${ }^{\circ} \mathrm{C} ;{ }^{1} \mathrm{H}$ NMR $\left(\mathrm{CDCl}_{3}, 300 \mathrm{MHz}\right) \delta 5.44(\mathrm{~s}, 2 \mathrm{H}), 6.85(\mathrm{dt}, J=9.0$, $3.4 \mathrm{~Hz}, 2 \mathrm{H}), 7.17(\mathrm{dt}, J=9.0,3.4 \mathrm{~Hz}, 2 \mathrm{H}), 7.35(\mathrm{t}, J=7.4 \mathrm{~Hz}$, $1 \mathrm{H}), 7.52-7.57(\mathrm{~m}, 1 \mathrm{H}), 7.69(\mathrm{~d}, J=7.9 \mathrm{~Hz}, 1 \mathrm{H}), 8.08-8.11(\mathrm{~m}$, $1 \mathrm{H}) ;{ }^{13} \mathrm{C}$ NMR $\left(\mathrm{CDCl}_{3}, 75 \mathrm{MHz}\right) \delta 68.6,116.4,126.1,126.6$, $127.5,127.7,129.5,131.9,133.8,140.3,157.4,172.0$. IR (KBr) v $\left[\mathrm{cm}^{-1}\right]=3439,3050,2901,1694,1599,1234$. HRMS (EI) $\mathrm{m} / \mathrm{z}=$ 262.0397 calcd for $\mathrm{C}_{14} \mathrm{H}_{11} \mathrm{ClO}_{3}$, found 262.0401.

2-((4-bromophenoxy)methyl)benzoic acid (2h). Isolated yield: $65 \%$ (white solid, $504 \mathrm{mg}, 1.65 \mathrm{mmol}$ ); mp 171-173 ${ }^{\circ} \mathrm{C} ;{ }^{1} \mathrm{H}$ $\operatorname{NMR}\left(\mathrm{CDCl}_{3}, 300 \mathrm{MHz}\right) \delta 5.52(\mathrm{~s}, 2 \mathrm{H}), 6.95-7.01(\mathrm{~m}, 2 \mathrm{H}), 7.43-$ $7.49(\mathrm{~m}, 3 \mathrm{H}), 7.62(\mathrm{dt}, J=7.6,1.4 \mathrm{~Hz}, 1 \mathrm{H}), 7.73(\mathrm{~d}, J=7.7 \mathrm{~Hz}$, $1 \mathrm{H}), 8.08(\mathrm{dd}, J=7.7,1.0 \mathrm{~Hz}, 1 \mathrm{H}) ;{ }^{13} \mathrm{C} \mathrm{NMR}\left(\mathrm{CDCl}_{3}, 75 \mathrm{MHz}\right)$ $\delta 69.1,113.4,120.1,128.4,128.5,131.9,132.2,133.4,140.1$, 159.1, 168.3. IR $(\mathrm{KBr}) \vee\left[\mathrm{cm}^{-1}\right]=3439,3050,2901,1694,1599$, 1234. HRMS (EI) $\mathrm{m} / \mathrm{z}=305.9892$ calcd for $\mathrm{C}_{14} \mathrm{H}_{11} \mathrm{BrO}_{3}$, found 305.9896 .

\section{Method B (2i-l)}

To a solution of $6.0 \mathrm{~g}(0.04 \mathrm{~mol})$ of methyl 2-methylbenzoate derivatives in $38 \mathrm{~mL}$ of chloroform, $7.5 \mathrm{~g}(0.042 \mathrm{~mol})$ of $\mathrm{N}$ bromosuccinimide and $0.078 \mathrm{~g}$ of benzoyl peroxide were added and carefully warmed up to $65^{\circ} \mathrm{C}$ until reaction started. Then the mixture was refluxed for $5 \mathrm{~h}$. After cooling down to room temperature, the deposit of succinimide was filtered. The solvent was removed under reduced pressure and the crude product was used in the next step without further purification. To a solution of functionalized methyl 2-(bromomethyl)benzoate $(6.55 \mathrm{mmol})$, substituted phenol $(8.5 \mathrm{mmol}), \mathrm{K}_{3} \mathrm{PO}_{4}(16.4 \mathrm{mmol})$ and toluene $20 \mathrm{~mL}$ were added to Schlenk under argon. The resulting solution was stirred to $110{ }^{\circ} \mathrm{C}$ for $5 \mathrm{~h}$. The progress of the reaction was monitored by TLC. The mixture was extracted with EtOAc, washed with water, brine and the combined organic layers were dried over anhydrous $\mathrm{Na}_{2} \mathrm{SO}_{4}$ and the solvent was removed under reduced pressure. The crude product was used in the next step without further purification. To the solution of the ester $(0.015$ $\mathrm{mol})$ in $\mathrm{MeOH}(73 \mathrm{~mL})$, was added $13 \mathrm{~mL}$ aqueous $\mathrm{KOH}(20 \%)$ and refluxed at $80^{\circ} \mathrm{C}$ for $5 \mathrm{~h}$. $\mathrm{MeOH}$ was removed and the aqueous phase was washed with DCM. After acidifying with $\mathrm{HCl}$ $(10 \%)$ the deposit was collected and washed with water.

2-((4-nitrophenoxy)methyl)benzoic acid (2i). Isolated yield: $40 \%$ (white solid, $543 \mathrm{mg}, 1.99 \mathrm{mmol}$ ); $\mathrm{mp} 143-145{ }^{\circ} \mathrm{C} ;{ }^{1} \mathrm{H} \mathrm{NMR}$ $\left(\mathrm{CDCl}_{3}, 300 \mathrm{MHz}\right) \delta 5.69(\mathrm{~s}, 2 \mathrm{H}), 7.21-7.24(\mathrm{~m}, 2 \mathrm{H}), 7.48-7.53$ $(\mathrm{m}, 1 \mathrm{H}), 7.62-7.68(\mathrm{~m}, 1 \mathrm{H}), 7.74(\mathrm{~d}, J=7.8 \mathrm{~Hz}, 1 \mathrm{H}), 8.10-8.12$ $(\mathrm{m}, 1 \mathrm{H}), 8.23-8.26(\mathrm{~m}, 2 \mathrm{H}) ;{ }^{13} \mathrm{C} \mathrm{NMR}\left(\mathrm{CDCl}_{3}, 75 \mathrm{MHz}\right) \delta 69.7$, $116.1,126.7,128.8,128.9,129.6,132.0,133.5,139.1,142.6$, 164.9, 168.3. IR $(\mathrm{KBr}) \vee\left[\mathrm{cm}^{-1}\right]=3240,2830,1695,1598,1270$. HRMS (EI) $\mathrm{m} / \mathrm{z}=273.0637$ calcd for $\mathrm{C}_{14} \mathrm{H}_{11} \mathrm{NO}_{5}$, found 273.0641.

2-((2,4-dichlorophenoxy)methyl)benzoic acid (2j). Isolated yield: $96 \%$ (white solid, $455 \mathrm{mg}, 1.50 \mathrm{mmol}$ ); $\mathrm{mp} 241-243{ }^{\circ} \mathrm{C} ;{ }^{1} \mathrm{H}$ NMR $\left(\mathrm{CDCl}_{3}, 300 \mathrm{MHz}\right) \delta 5.59(\mathrm{~s}, 2 \mathrm{H}), 6.92-6.95(\mathrm{~m}, 1 \mathrm{H}), 7.19$ $(\mathrm{dd}, J=8.7,2.5 \mathrm{~Hz}, 1 \mathrm{H}), 7.40-7.48(\mathrm{~m}, 2 \mathrm{H}), 7.68(\mathrm{dt}, J=7.6,1.3$ $\mathrm{Hz}, 1 \mathrm{H}), 7.92(\mathrm{~d}, J=7.7 \mathrm{~Hz}, 1 \mathrm{H}), 8.19(\mathrm{dd}, J=7.8,1.2 \mathrm{~Hz}, 1 \mathrm{H})$; ${ }^{13} \mathrm{C} \mathrm{NMR}\left(\mathrm{CDCl}_{3}, 75 \mathrm{MHz}\right) \delta 69.3,114.7,124.0,126.1,126.2$, 127.3, 127.7, 127.8, 130.2, 132.0, 134.1, 139.9, 153.1, 172.2. IR $(\mathrm{KBr}) v\left[\mathrm{~cm}^{-1}\right]=3270,2828,1699,1262$. HRMS (EI) $\mathrm{m} / \mathrm{z}=$ 296.0007 calcd for $\mathrm{C}_{14} \mathrm{H}_{10} \mathrm{Cl}_{2} \mathrm{O}_{3}$, found 296.0011.

4-nitro-2-(phenoxymethyl)benzoic acid $(2 \mathrm{k}) .{ }^{15 \mathrm{f}}$ Isolated yield: $68 \%$ (white solid, $464 \mathrm{mg}, 1.70 \mathrm{mmol}$ ); mp 179-180 ${ }^{\circ} \mathrm{C} ;{ }^{1} \mathrm{H}$ NMR $\left(\mathrm{CDCl}_{3}, 300 \mathrm{MHz}\right) \delta 5.19(\mathrm{~s}, 2 \mathrm{H}), 6.91-712(\mathrm{~m}, 1 \mathrm{H}), 7.28-7.33$ (m, 2H), 7.34-7.68 (m, 2H), $8.30(\mathrm{dd}, J=7.5 \mathrm{~Hz}, 1 \mathrm{H}), 8.45$ (dd, $1 \mathrm{H}), 8.23-8.26(\mathrm{~m}, 1 \mathrm{H})$; ${ }^{13} \mathrm{C} \mathrm{NMR}\left(\mathrm{CDCl}_{3}, 75 \mathrm{MHz}\right) \delta 67.4$, $114.9,121.5,121.9,125.1,129.4,129.5,130.3,135.6,144.9$, 149.3, 169.8. IR $(\mathrm{KBr}) \vee\left[\mathrm{cm}^{-1}\right]=3340,2880,1691,1600,1524$, 1495, 1270. HRMS (EI) $\mathrm{m} / \mathrm{z}=273.0637$ calcd for $\mathrm{C}_{14} \mathrm{H}_{11} \mathrm{NO}_{5}$, found 273.0642 .

4-methoxy-2-(phenoxymethyl)benzoic acid (2l). ${ }^{15 \mathrm{c}}$ Isolated yield: $88 \%$ (white solid, $454 \mathrm{mg}, 1.76 \mathrm{mmol}$ ); $\mathrm{mp} 160-162{ }^{\circ} \mathrm{C} ;{ }^{1} \mathrm{H}$ $\mathrm{NMR}\left(\mathrm{CDCl}_{3}, 300 \mathrm{MHz}\right) \delta 3.73(\mathrm{~s}, 3 \mathrm{H}), 5.42(\mathrm{~s}, 2 \mathrm{H}), 6.87-6.95$ (m, 1H), 6.97-7.10 (m, 1H), 7.11-7.18 (m, 2H), $7.24(\mathrm{dd}, 1 \mathrm{H})$, 7.26-7.34 (m, 2H), $7.95(\mathrm{~d}, J=7.5 \mathrm{~Hz}, 1 \mathrm{H}) ;{ }^{13} \mathrm{C}$ NMR $\left(\mathrm{CDCl}_{3}\right.$, $75 \mathrm{MHz}) \delta 55.3,67.4,111.5,112.8,114.4,114.9,121.5,129.4$, 131.1, 137.6, 149.3, 159.9, 168.8. IR (KBr) $v\left[\mathrm{~cm}^{-1}\right]=3435$, 3039, 2905, 1696, 1599, 1241. HRMS (EI) $\mathrm{m} / \mathrm{z}=258.0892$ calcd for $\mathrm{C}_{15} \mathrm{H}_{14} \mathrm{O}_{4}$, found 258.0896 . 
4.3. General procedure for synthesis of dibenzo[b,e]oxepin11(6H)-ones (1a-1l).

Functionalized 2-(phenoxymethyl)benzoic acid $(1.0 \mathrm{mmol})$, $\mathrm{FeCl}_{2}$ (0.6 equiv), dichloromethyl methyl ether (1.0 equiv) (CAUTION), and $\mathrm{CH}_{2} \mathrm{Cl}_{2}(10 \mathrm{~mL})$ were added to a Schlenk tube under argon. The resulting solution was stirred at room temperature until the completion of the reaction. The progress of the reaction was monitored by TLC and GC-MS. The reaction was quenched by addition of water. The mixture was extracted with $\mathrm{CH}_{2} \mathrm{Cl}_{2}$, washed with aqueous saturated $\mathrm{NaHCO}_{3}$ and then the combined organic layers were dried over anhydrous $\mathrm{Na}_{2} \mathrm{SO}_{4}$, filtered and the solvent was removed under reduced pressure. The crude product was purified by column chromatography using silica gel 60 or recrystallized in ethanol.

dibenzo[b,e]oxepin-11(6H)-one (1a). ${ }^{15 a}$ Isolated yield: $88 \%$ (white solid, $120 \mathrm{mg}, 0.58 \mathrm{mmol}$, eluent: hexane/EtOAc 90:10); mp 65-67 ${ }^{\circ} \mathrm{C}$; ${ }^{1} \mathrm{H}$ NMR $\left(\mathrm{CDCl}_{3}, 300 \mathrm{MHz}\right) \delta 5.19$ (s, 2H), 7.04$7.15(\mathrm{~m}, 2 \mathrm{H}), 7.35-7.38(\mathrm{~m}, 1 \mathrm{H}), 7.44-7.58(\mathrm{~m}, 3 \mathrm{H}), 7.90(\mathrm{dd}, J=$ 7.6, $1.3 \mathrm{~Hz}, 1 \mathrm{H}), 8.25(\mathrm{dd}, J=8.0,1.9 \mathrm{~Hz}, 1 \mathrm{H}) ;{ }^{13} \mathrm{C} \mathrm{NMR}$ $\left(\mathrm{CDCl}_{3}, 75 \mathrm{MHz}\right) \delta 73.7,120.8,122.2,125.5,127.9,129.3$, 129.6, 132.1, 132.8, 135.4, 135.7, 140.7, 161.4, 191.2. MS m/z: 210 (100), 181 (80), 152 (29), 89 (15), 76 (15), 63 (12). IR (KBr) $v\left[\mathrm{~cm}^{-1}\right]=2921,2870,1653,1456$. HRMS (EI) $\mathrm{m} / \mathrm{z}=210.0681$ calcd for $\mathrm{C}_{14} \mathrm{H}_{10} \mathrm{O}_{2}$, found 210.0685 .

4-methyldibenzo[b,e]oxepin-11(6H)-one $\quad(\mathbf{1 b}) .^{36} \quad$ Isolated yield: $90 \%$ (white solid, $170 \mathrm{mg}, 0.75 \mathrm{mmol}$, eluent: hexane/EtOAc 90:10); mp 68-70 ${ }^{\circ} \mathrm{C} ;{ }^{1} \mathrm{H} \mathrm{NMR}\left(\mathrm{CDCl}_{3}, 300\right.$ MHz) $\delta 2.28(\mathrm{~s}, 3 \mathrm{H}), 5.23(\mathrm{~s}, 2 \mathrm{H}), 7.01(\mathrm{t}, J=7.7 \mathrm{~Hz}, 1 \mathrm{H}), 7.35-$ $7.39(\mathrm{~m}, 2 \mathrm{H}), 7.43-7.49(\mathrm{~m}, 1 \mathrm{H}), 7.55(\mathrm{dt}, J=7.5,1.2 \mathrm{~Hz}, 1 \mathrm{H})$, $7.89(\mathrm{dd}, J=7.5,0.8 \mathrm{~Hz}, 1 \mathrm{H}), 8.10(\mathrm{dd}, J=8.3,1.4 \mathrm{~Hz}, 1 \mathrm{H}) ;{ }^{13} \mathrm{C}$ NMR $\left(\mathrm{CDCl}_{3}, 75 \mathrm{MHz}\right) \delta 16.8,73.6,121.6,125.5,127.6,129.3$, 129.4, 129.5, 130.0, 132.7, 135.9, 136.4, 140.7, 159.7, 191.6. MS m/z: 224 (100), 209 (25), 195 (36), 181 (34), 165 (19), 152 (20), 115 (6), 89 (19). IR (KBr) $v\left[\mathrm{~cm}^{-1}\right]=3068,2945,2856,1654$, 1471, 808, 751. HRMS (EI) $\mathrm{m} / \mathrm{z}=224.0837$ calcd for $\mathrm{C}_{15} \mathrm{H}_{12} \mathrm{O}_{2}$, found 224.0832 .

3-methoxydibenzo[b,e]oxepin-11(6H)-one $(1 c))^{15 \mathrm{c}}$ Isolated yield: $84 \%$ (light brown solid, $160 \mathrm{mg}, 0.65 \mathrm{mmol}$, eluent: hexane/EtOAc 90:10); mp 135-137 ${ }^{\circ} \mathrm{C} ;{ }^{1} \mathrm{H}$ NMR (Acetone- $d_{6}$, $300 \mathrm{MHz}) \delta 3.86(\mathrm{~s}, 3 \mathrm{H}), 5.25(\mathrm{~s}, 2 \mathrm{H}), 6.54(\mathrm{~d}, J=2.5 \mathrm{~Hz}, 1 \mathrm{H})$, $6.74(\mathrm{dd}, J=9.1,2.5 \mathrm{~Hz}, 1 \mathrm{H}), 7.34(\mathrm{~s}, 1 \mathrm{H}), 7.47-7.52(\mathrm{~m}, 1 \mathrm{H})$, 7.57-7.63 (m, 1H), 7.84-7.87 (m, 1H), $8.15(\mathrm{~d}, J=9.1 \mathrm{~Hz}, 1 \mathrm{H})$; ${ }^{13} \mathrm{C}$ NMR (Acetone- $\left.d_{6}, 75 \mathrm{MHz}\right) \delta 56.7,74.8,104.6,111.7$, $129.5,129.3,130.4,130.5,133.8,134.8,137.4,141.9,164.7$, 166.9, 189.6. MS m/z: 240 (100), 211 (22), 197 (30), 168 (10), 141 (12), $115(11), 89$ (11). IR $(\mathrm{KBr}) \vee\left[\mathrm{cm}^{-1}\right]=3065,2953$, 1723, 1490, 853. HRMS (EI) $\mathrm{m} / \mathrm{z}=240.0786$ calcd for $\mathrm{C}_{15} \mathrm{H}_{12} \mathrm{O}_{3}$, found 240.0781 .

2-methoxydibenzo[b,e]oxepin-11(6H)-one $\quad(1 d) .{ }^{37}$ Isolated yield: $90 \%$ (white solid, $80 \mathrm{mg}, 0.35 \mathrm{mmol}$ ); mp 96-98 ${ }^{\circ} \mathrm{C} ;{ }^{1} \mathrm{H}$ $\mathrm{NMR}\left(\mathrm{CDCl}_{3}, 300 \mathrm{MHz}\right) \delta 3.85(\mathrm{~s}, 3 \mathrm{H}), 5.15(\mathrm{~s}, 2 \mathrm{H}), 6.97-7.00$ $(\mathrm{m}, 1 \mathrm{H}), 7.07-7.11(\mathrm{~m}, 1 \mathrm{H}), 7.34-7.36(\mathrm{~m}, 1 \mathrm{H}), 7.44-7.58(\mathrm{~m}$, 2H), 7.69-7.70 (m, 1H), $7.93(\mathrm{~d}, J=7.6 \mathrm{~Hz}, 1 \mathrm{H}) ;{ }^{13} \mathrm{C} \mathrm{NMR}$ $\left(\mathrm{CDCl}_{3}, 75 \mathrm{MHz}\right) \delta 55.9,74.1,112.5,122.1,124.4,125.6,127.8$, 129.2, 129.9, 132.9, 136.2, 140.0, 154.6, 156.1, 190.6. MS m/z: 240 (100), 225 (38), 211 (18), 197 (20), 169 (11), 141 (22), 115 (28), 89 (13). IR (KBr) $v\left[\mathrm{~cm}^{-1}\right]=3072,2962,2921,1720,1486$, 829, 796. HRMS (EI) $\mathrm{m} / \mathrm{z}=240.0786$ calcd for $\mathrm{C}_{15} \mathrm{H}_{12} \mathrm{O}_{3}$, found 240.0782 .

4-methoxydibenzo[b,e]oxepin-11(6H)-one $\quad(1 e) .^{38}$ Isolated yield: $87 \%$ (light brown solid, $40 \mathrm{mg}, 0.17 \mathrm{mmol}$ ); $\mathrm{mp} 70-72{ }^{\circ} \mathrm{C}$; ${ }^{1} \mathrm{H}$ NMR $\left(\mathrm{CDCl}_{3}, 300 \mathrm{MHz}\right) \delta 3.83(\mathrm{~s}, 3 \mathrm{H}), 5.23$ (s, 2H), 6.98$7.02(\mathrm{~m}, 2 \mathrm{H}), 7.29-7.31(\mathrm{~m}, 1 \mathrm{H}), 7.39$ (dt, $J=7.6,1.2 \mathrm{~Hz}, 1 \mathrm{H})$, $7.48(\mathrm{dt}, J=7.5,1.3,1 \mathrm{H}), 7.74(\mathrm{dd}, J=7.2,2.7 \mathrm{~Hz}, 1 \mathrm{H}), 7.79$ $(\mathrm{dd}, J=7.5,1.3 \mathrm{~Hz}, 1 \mathrm{H}) ;{ }^{13} \mathrm{C} \mathrm{NMR}\left(\mathrm{CDCl}_{3}, 75 \mathrm{MHz}\right) \delta 56.5$, 74.2, 116.2, 121.5, 123.0, 126.3, 127.9, 129.3, 129.4, 132.8, 135.3, 140.8, 150.7, 151.6, 191.5. MS m/z: 240 (100), 225 (11), 211 (26), 197 (27), 181 (22), 169 (15), 152 (16), 141 (20), 115 (28), 89 (18), 63 (11). IR (KBr) $\vee\left[\mathrm{cm}^{-1}\right]=3070,2960,2918$, 1711, 1476, 829, 794. HRMS (EI) $\mathrm{m} / \mathrm{z}=240.0786$ calcd for $\mathrm{C}_{15} \mathrm{H}_{12} \mathrm{O}_{3}$, found 240.0780 .

3-hydroxydibenzo[b,e]oxepin-11(6H)-one (1f). Isolated yield: $81 \%$ (brown solid, $110 \mathrm{mg}, 0.50 \mathrm{mmol}$ ); mp $138-140{ }^{\circ} \mathrm{C} ;{ }^{1} \mathrm{H}$ NMR $\left(\mathrm{CDCl}_{3}, 300 \mathrm{MHz}\right) \delta 5.30(\mathrm{~s}, 2 \mathrm{H}), 6.81-6.87(\mathrm{~m}, 1 \mathrm{H}), 7.03-$ $7.06(\mathrm{~m}, 1 \mathrm{H}), 7.16(\mathrm{~d}, J=6.5 \mathrm{~Hz}, 1 \mathrm{H}), 7.38(\mathrm{~d}, J=6.3 \mathrm{~Hz}, 1 \mathrm{H})$, 7.50-7.58 (m, 2H), $7.75(\mathrm{~d}, J=7.8 \mathrm{~Hz}, 1 \mathrm{H}), 7.94(\mathrm{~d}, J=6.8 \mathrm{~Hz}$, $1 \mathrm{H}) ;{ }^{13} \mathrm{C} \mathrm{NMR}\left(\mathrm{CDCl}_{3}, 75 \mathrm{MHz}\right) \delta 74.8,119.9,1226 ., 122.7$, 128.0, 129.7, 130.0, 133.0, 134.2, 135.1, 140.5, 147.2, 148.4, 190.6. MS m/z: 226 (100), 197 (43), 181 (17), 164 (14), 152 (15), 141 (21), 115 (17), 89 (15). IR (KBr) $\vee\left[\mathrm{cm}^{-1}\right]=3432,2966$, 2922, 1650, 1270, 1106, 1023, 804. HRMS (EI) m/z = 226.0630 calcd for $\mathrm{C}_{14} \mathrm{H}_{10} \mathrm{O}_{3}$, found 226.0635 .

2-chlorodibenzo[b,e]oxepin-11(6H)-one $\quad(\mathbf{l g}) .^{20} \quad$ Isolated yield: $75 \%$ (white solid, $140 \mathrm{mg}, 0.57 \mathrm{mmol}$ ); $\mathrm{mp} 117-119{ }^{\circ} \mathrm{C} ;{ }^{1} \mathrm{H}$ $\mathrm{NMR}\left(\mathrm{CDCl}_{3}, 300 \mathrm{MHz}\right) \delta 5.18(\mathrm{~s}, 2 \mathrm{H}), 7.01(\mathrm{~d}, J=8.8 \mathrm{~Hz}, 1 \mathrm{H})$, 7.35-7.43 (m, 2H), $7.48(\mathrm{dt}, J=76,1.1 \mathrm{~Hz}, 1 \mathrm{H}), 7.58(\mathrm{dt}, J=7.6$, $1.2 \mathrm{~Hz}, 1 \mathrm{H}), 7.89(\mathrm{dd}, J=7.6,1.0 \mathrm{~Hz}, 1 \mathrm{H}), 8.20(\mathrm{~d}, J=2.7 \mathrm{~Hz}$, $1 \mathrm{H}) ;{ }^{13} \mathrm{C} \mathrm{NMR}\left(\mathrm{CDCl}_{3}, 75 \mathrm{MHz}\right) \delta 73.9,122.5,126.4,127.7$, 128.0, 129.6, 129.8, 131.2, 133.2, 135.2, 135.5, 140.0, 159.9, 189.8. MS m/z: 246 (33), 244 (100), 217 (12), 215 (34), 209 (36), $181(37), 152(48), 89(21), 76(18), 63(21)$. IR (KBr) $v\left[\mathrm{~cm}^{-1}\right]=$ $3071,2956,2923,1646,1470,837,825$. HRMS (EI) $\mathrm{m} / \mathrm{z}=$ 244.0291 calcd for $\mathrm{C}_{14} \mathrm{H}_{9} \mathrm{ClO}_{2}$, found 244.0295.

2-bromodibenzo[b,e]oxepin-11(6H)-one $\quad(\mathbf{1 h}) .^{39} \quad$ Isolated yield: $71 \%$ (white solid, $130 \mathrm{mg}, 0.46 \mathrm{mmol}$ ); $\mathrm{mp} 122-124{ }^{\circ} \mathrm{C} ;{ }^{1} \mathrm{H}$ $\mathrm{NMR}\left(\mathrm{CDCl}_{3}, 300 \mathrm{MHz}\right) \delta 5.18(\mathrm{~s}, 2 \mathrm{H}), 6.95(\mathrm{~d}, J=8.7 \mathrm{~Hz}, 1 \mathrm{H})$, 7.37 (d, $J=7.2 \mathrm{~Hz}, 1 \mathrm{H}), 7.46-7.60(\mathrm{~m}, 3 \mathrm{H}), 7.89(\mathrm{~d}, J=7.5 \mathrm{~Hz}$, $1 \mathrm{H}), 8.35(\mathrm{~d}, J=2.4 \mathrm{~Hz}, 1 \mathrm{H}) ;{ }^{13} \mathrm{C} \mathrm{NMR}\left(\mathrm{CDCl}_{3}, 75 \mathrm{MHz}\right) \delta 73.9$, $114.9,122.9,126.8,128.1,129.6,129.8,133.2,134.3,135.4$, 138.0, 140.1, 160.4, 189.8. MS m/z: 290 (96), 288 (100), 261 (20), 259 (21), 209 (39), 181 (41), 152 (66), 89 (32), 76 (26), 63 (31). IR (KBr) $\vee\left[\mathrm{cm}^{-1}\right]=3074,2958,2930,1646,1470,837$, 760. HRMS (EI) $\mathrm{m} / \mathrm{z}=287.9786$ calcd for $\mathrm{C}_{14} \mathrm{H}_{9} \mathrm{BrO}_{2}$, found 287.9790 .

2-nitrodibenzo[b,e]oxepin-11(6H)-one (1i). Isolated yield: $61 \%$ (light brown solid, $150 \mathrm{mg}, 0.61 \mathrm{mmol}$, eluent: hexane/EtOAc 90:10); mp 151-153 ${ }^{\circ} \mathrm{C} .{ }^{1} \mathrm{H}$ NMR $\left(\mathrm{CDCl}_{3}, 300\right.$ $\mathrm{MHz}) \delta 4.11(\mathrm{~s}, 2 \mathrm{H}), 7.31-7.42(\mathrm{~m}, 3 \mathrm{H}), 7.54(\mathrm{dt}, J=7.6,1.3 \mathrm{~Hz}$, $1 \mathrm{H}), 7.90(\mathrm{dd}, J=7.6,0.9 \mathrm{~Hz}, 1 \mathrm{H}), 8.11-8.15(\mathrm{~m}, 1 \mathrm{H}), 8.2(\mathrm{~d}, J=$ $2.6 \mathrm{~Hz}, 1 \mathrm{H}) ;{ }^{13} \mathrm{C} \mathrm{NMR}\left(\mathrm{CDCl}_{3}, 75 \mathrm{MHz}\right) \delta 77.4,122.0,124.0$, $124.2,127.5,128.3,133.2,134.0,134.3,141.1,145.2,155.4$, $164.3,207.1$. IR (KBr) $v\left[\mathrm{~cm}^{-1}\right]=3052,2957,2929,1654,1590$, 1260, 800. HRMS (ESI) $\mathrm{m} / \mathrm{z}=278.0430$ calcd for $\mathrm{C}_{14} \mathrm{H}_{9} \mathrm{NNaO}_{4}$ $[\mathrm{M}+\mathrm{Na}]^{+}$, found: 278.0426 .

2,4-dichlorodibenzo[b,e]oxepin-11(6H)-one (1j). Isolated yield: $70 \%$ (white solid, $190 \mathrm{mg}, 0.70 \mathrm{mmol}$, eluent: hexane/EtOAc 90:10); mp 138-140 ${ }^{\circ} \mathrm{C} ;{ }^{1} \mathrm{H}$ NMR $\left(\mathrm{CDCl}_{3}, 300\right.$ MHz) $\delta 5.30(\mathrm{~s}, 2 \mathrm{H}), 7.41(\mathrm{~d}, J=7.2 \mathrm{~Hz}, 1 \mathrm{H}), 7.50(\mathrm{dt}, J=7.5$, $0.8 \mathrm{~Hz}, 1 \mathrm{H}), 7.58-7.63(\mathrm{~m}, 2 \mathrm{H}), 7.87-7.90(\mathrm{~m}, 1 \mathrm{H}), 8.13$ (d, $J=$ $2.7 \mathrm{~Hz}, 1 \mathrm{H}) ;{ }^{13} \mathrm{C} \mathrm{NMR}\left(\mathrm{CDCl}_{3}, 75 \mathrm{MHz}\right) \delta 72.6,124.8,125.4$, $125.5,126.3,127.9,128.0,128.3,131.6,133.2,133.3,137.8$, 153.8, 187.2; MS m/z: 282 (9), 280 (65), 278 (100), 251 (19), 249 (29), 245 (18), 243 (51), 217 (11), 215 (32), 186 (13), 152 (38), 89 (23), 63 (12). IR (KBr) $v\left[\mathrm{~cm}^{-1}\right]=3068,2955,2926$, 1652, 1467, 823, 813. HRMS (EI) $\mathrm{m} / \mathrm{z}=277.9901$ calcd for $\mathrm{C}_{14} \mathrm{H}_{8} \mathrm{Cl}_{2} \mathrm{O}_{2}$, found 277.9905 . 
8-nitrodibenzo[b,e]oxepin-11(6H)-one $(1 k) .{ }^{15 f}$ Isolated yield: 92\% (light solid, $230 \mathrm{mg}, 0.92 \mathrm{mmol}$, eluent: hexane/EtOAc 90:10); mp 179-181 ${ }^{\circ} \mathrm{C} ;{ }^{1} \mathrm{H}$ NMR (DMSO- $\left.d_{6}, 300 \mathrm{MHz}\right) \delta 5.45$ $(\mathrm{s}, 2 \mathrm{H}), 7.12-7.21(\mathrm{~m}, 2 \mathrm{H}), 7.61(\mathrm{t}, J=7.6,1.3 \mathrm{~Hz}, 1 \mathrm{H}), 7.95-$ $8.01(\mathrm{~m}, 2 \mathrm{H}), 8.52(\mathrm{~d}, J=2.6 \mathrm{~Hz}, 1 \mathrm{H}), 8.55(\mathrm{~s}, 1 \mathrm{H}) ;{ }^{13} \mathrm{C} \mathrm{NMR}$ $\left(\mathrm{DMSO}-d_{6}, 75 \mathrm{MHz}\right) \delta 70.6,115.1,123.1,123.4,125.1,127.4$, 129.3, 130.6, 133.2, 140.0, 140.8, 147.2, 157.1, 199.7. IR (KBr) $v\left[\mathrm{~cm}^{-1}\right]=3050,2956,2927,1653,1591,1260,799$. HRMS (ESI) $\mathrm{m} / \mathrm{z}=278.0430$ calcd for $\mathrm{C}_{14} \mathrm{H}_{9} \mathrm{NNaO}_{4}[\mathrm{M}+\mathrm{Na}]^{+}$, found: 278.0427 .

\section{8-methoxydibenzo[b,e]oxepin-11(6H)-one $\quad(11) .{ }^{15 c} \quad$ Isolated} yield: $87 \%$ (light solid, $210 \mathrm{mg}, 0.87 \mathrm{mmol}$, eluent: hexane/EtOAc 90:10); mp 130-132 ${ }^{\circ} \mathrm{C} ;{ }^{1} \mathrm{H}$ NMR (DMSO- $d_{6}, 300$ $\mathrm{MHz}) \delta 3.89(\mathrm{~s}, 3 \mathrm{H}), 5.28(\mathrm{~s}, 2 \mathrm{H}), 7.08(\mathrm{dd}, J=8.7,2.3 \mathrm{~Hz}, 1 \mathrm{H})$, 7.10-7.16 (m, 2H), 7.20 (t, $J=7.4 \mathrm{~Hz}, 1 \mathrm{H}), 7.58$ (brs t, $J=7.6$ $\mathrm{Hz}, 1 \mathrm{H}), 7.89(\mathrm{t}, J=8.7 \mathrm{~Hz}, 1 \mathrm{H}), 8.20(\mathrm{dd}, J=8.1,1.3 \mathrm{~Hz}, 1 \mathrm{H})$; ${ }^{13} \mathrm{C}$ NMR (DMSO- $\left.d_{6}, 75 \mathrm{MHz}\right) \delta 55.6,73.2,113.1,114.5,120.6$, $122.2,125.5,131.5,131.8,132.1,135.2,138.8,160.7,163.0$, 187.7. MS m/z: 240 (100), 211 (20), 197 (27), 168 (12), 141 (11), 115 (10), 89 (12). IR (KBr) $v\left[\mathrm{~cm}^{-1}\right]=3055,2953,2925,1715$, 1495, 851. HRMS (EI) $\mathrm{m} / \mathrm{z}=240.0786$ calcd for $\mathrm{C}_{15} \mathrm{H}_{12} \mathrm{O}_{3}$, found 240.0782 .

\subsection{Synthesis of 3-(dibenzo[b,e]oxepin-11(6H)-ylidene)- $N, N$ -} dimethylpropan-1-amine (3).

3-(N,N-dimethylamino)propylmagnesium chloride was prepared from magnesium turnings $(0.04 \mathrm{~mol})$ activated with iodine at $75{ }^{\circ} \mathrm{C}$ for $1 \mathrm{~h}$. THF $(1 \mathrm{~mL})$, toluene $(4 \mathrm{~mL})$ and some drops of methyl iodide was added at $65{ }^{\circ} \mathrm{C}$ and stirred for $30 \mathrm{~min}$ 3 -chloro- $\mathrm{N}, \mathrm{N}$-dimethylpropylamine $(0.03 \mathrm{~mol})$ in toluene $(15$ $\mathrm{mL}$ ) was added slowly. After $30 \mathrm{~min} \mathbf{1 a}(0.02 \mathrm{~mol})$ in $10 \mathrm{~mL}$ toluene was added. The reaction mixture was stirred vigorously at $65{ }^{\circ} \mathrm{C}$ for $2 \mathrm{~h}$. Then, concentrated hydrochloric acid $(20 \mathrm{~mL})$ was added slowly $\left(30 \mathrm{~min}\right.$.) at $65{ }^{\circ} \mathrm{C}$ and the reaction mixture was stirred for $1 \mathrm{~h}$. The organic phase was separated and the aqueous phase extracted with diethyl ether $(200 \mathrm{~mL})$. The aqueous phase was made alkaline with aqueous ammonia and extracted with diethyl ether. The organic phase was dried over anhydrous $\mathrm{Na}_{2} \mathrm{SO}_{4}$, filtered and the diethyl ether was removed under reduced pressure to give $190 \mathrm{mg}(0.7 \mathrm{mmol}, 70 \%)$ of $\mathbf{3}$ as a colourless oil. The ${ }^{1} \mathrm{H}$ NMR spectrum of the reaction crude product showed it to consist of a mixture the expected geometric $E$ - $(80 \%)$ and Z- $(20 \%)$ isomers in different proportions. The majority (E)-diastereoisomer was easily separated by crystallisation of the corresponding maleate. ${ }^{22 \mathrm{e}}{ }^{1} \mathrm{H} \mathrm{NMR}\left(\mathrm{CDCl}_{3}\right.$, $300 \mathrm{MHz}) \delta 2.60-2.74(\mathrm{~m}, 4 \mathrm{H}), 2.70(\mathrm{~s}, 6 \mathrm{H}), 4.80$ (brs, 1H), 5.50 (brs, $1 \mathrm{H}),{ }^{40} 5.91(\mathrm{t}, J=7.0 \mathrm{~Hz}, 1 \mathrm{H}), 6.75-7.40(\mathrm{~m}, 8 \mathrm{H}) ;{ }^{13} \mathrm{C} \mathrm{NMR}$ $\left(\mathrm{CDCl}_{3}, 75 \mathrm{MHz}\right) \delta 24.9,42.4,60.2,73.7,119.2,121.2,127.5$, $127.9,128.2,128.3,128.5,128.8,129.4,130.3,134.4,141.1$, 141.3, 155.2. MS m/z: 279 (40), 219 (22), 282 (25), 189 (30), 178 (40), 165 (45), $115(25), 59(50), 58(100) . \mathrm{IR}(\mathrm{KBr}) v\left[\mathrm{~cm}^{-1}\right]$ $=3050,3025,1698,1582,1483,1431$. HRMS (EI) $\mathrm{m} / \mathrm{z}=$ 279.1623 calcd for $\mathrm{C}_{19} \mathrm{H}_{21} \mathrm{NO}$, found 279.1628.

\subsection{Anthelmintic assays using C. elegans}

The $C$. elegans wild-type (Bristol variety) strain was obtained from the Caenorhabditis Genetic Center, which is funded by the NIH National Center for Research Resources (NCRR). Nematodes were raised at $21{ }^{\circ} \mathrm{C}$ under standard laboratory conditions on agar plates cultured with Escherichia coli (OP50). ${ }^{23}$ Thrashing assays were used to measure worm motility essentially as described before. ${ }^{41}$ Worms were synchronously grown to early adult stage. Individual young adult $C$. elegans were placed in
$100 \mu \mathrm{l}$ of M9 buffer $\left(3 \mathrm{~g} / \mathrm{L} \mathrm{KH} \mathrm{KH}_{2} \mathrm{PO}_{4}, 6 \mathrm{~g} / \mathrm{L} \mathrm{Na}_{2} \mathrm{HPO}_{4}, 5 \mathrm{~g} / \mathrm{L}\right.$ $\left.\mathrm{NaCl}, 0.25 \mathrm{~g} / \mathrm{L} \mathrm{MgSO}_{4} .7 \mathrm{H}_{2} \mathrm{O}\right)$ in the absence or presence of the compound under study $(1 \mathrm{mM} / \mathrm{DMSO} 1 \%)$ in a 96 -well microlitre plate. After 10 minutes, the number of thrashes were counted for $30 \mathrm{~s}$. A single thrash was defined as a complete change in the direction of bending at the mid body. The experiments were repeated 3 times for each condition (20 worms tested each time). All assays were blind and carried out at 20-22 ${ }^{\circ} \mathrm{C}$. Data are shown as mean \pm S.D. Statistical comparisons were done using the oneway ANOVA with Bonferroni's multiple comparison posttest. Thrashing rates lower than those of control worms with $\mathrm{p}<0.05$ were considered significant. The halfinhibition concentration, $\mathrm{IC}_{50}$, was obtained from the curve resulting from the percentage of thrashes/ min in the presence of compound 1a respect to the buffer condition.

\section{Acknowledgments}

This work was generously supported by the Consejo Nacional de Investigaciones Científicas y Técnicas (CONICET), Agencia Nacional de Promoción Científica y Tecnológica (ANPCyT) and Universidad Nacional del Sur (UNS) from Argentina to DCG and $\mathrm{CB}$, and a Grand Challenges Explorations Grant from Bill and Melinda Gates Foundation to CB (OPP1098404). CB and DCG are research members of CONICET. MBF is research member of CIC. JS and MJC thank the CONICET for a postdoctoral fellowship.

\section{References}

1. Waller, P. J. Int. J. Parasitol. 1999, 29, 155-164.

2. Mehlhorn, H.; Al-Quraishy, S.; Al-Rasheid, K. A.; Jatzlau, A.; AbdelGhaffar, F. Parasitol. Res. 2011, 108, 1041-1046.

3. Simpkin, K. G.; Coles, G. C. C. J. Chem. Technol. Biotechnol. 1981, 31, 66-69.

4. Thompson, D. P.; Klein, R. D.; Geary, T. G. Parasitology 1996, 113, S217-S238.

5. Newman, D. J.; Cragg, G. M. J. Nat. Prod. 2012, 75, 311-335.

6. (a) Molinski, T. F.; Dalisay, D. S.; Lievens, S. L.; Saludes, J. P. Nature Reviews Drug Discovery 2009, 8, 69-85; (b) Njardarson, J. T.; Gaul, C.; Shan, D.; Huang, X. Y.; Danishefsky, S. D. J. Am. Chem. Soc. 2004, 126, 1038-1040.

7. (a) Bloom, B. M.; Tretter, J. R. Belg. Patent 641 498, 1964; (b) Stach, K.; Bickelkaupt, F. Mon. Chem. 1962, 93, 896-904.

8. Stach, K. U.S. Patent $3438981,1969$.

9. (a) Ueno, K.; Kubo, S.; Yoshioka, T.; Tagawa, H.; Shimada, S.; Kojima, H.; Tsukada, H.; Tsubolawa, M. Jap. Patent 800 0377, 1980; (b) Ueno, K.; Kubo, S.; Tagawa, H.; Yoshioka, T.; Teukada W.; Tsubokawa, M.; Kojima, H.; Kasahara, A. J. Med. Chem. 1976, 19, 941-946.

10. King, A. C.; Chapel Hill, N. C. U.S. Patent 300 282, 1994

11. Shen, K.-Z.; Gao, S.; Gao, Y. X.; Wang, A. R.; Xu, Y. B.; Sun, R.; Hu, P. G.; Yang, G. F.; Li, A. J.; Zhong, D.; Liu, H. Y.; Dong, J. Y. Planta Med. 2012, 78, 1837-1843.

12. Junzhi, Q.; Xiaoxia, L.; Jiao, F.; Lihui, M.; Qingfeng, G.; Xiaoyun, H.; Jie, T.; Yunfeng, Q.; Wei, Z.; Xiaocong, X. Chem. Abstr. 2013, 158, 532348.

13. Li, E.; Jiang, L.; Guo, L.; Zhang, H.; Che, Y. Bioorg. Med. Chem. 2008, 16, 7894-7899.

14. (a) Feldmann, M. B.; Fionula, M.; Maini, R. N. Annu. Rev. Immunol. 1996, 14, 397-440; (b) Baur, B.; Storch, K.; Martz, K. E.; Goettert, M. I.; Richters, A.; Rauh, D.; Laufer, S. A. J. Med. Chem. 2013, 56, 85618578 .

15. (a) Sadek, B.; Limban, C.; Stecoza, C. E.; Elz, S. Sci. Pharm. 2011, 79, 749-761; (b) Rudorf, W.; Baumeister, U.; Florea, S.; Nicolae, A.; Maior, O. Monatsh. Chem. 1999, 130, 1475-1480; (c) Andrews, B.; Bullock, K.; Condon, S.; Corona, J.; Davis, R.; Grimes, J.; Hazelwood, A.; Tabet, E. Synth. Commun. 2009, 39, 2664-2673; (d) Richey, R. N.; Yu, H. Org. Process Res. Dev. 2009, 13, 315-320; (e) Kluge, A. F.; Caroon, J. M.; Unger, S. H.; Ryley, J. F. J. Med. Chem. 1978, 21, 529536; (f) Laufer, S. A.; Ahrens, G. M.; Karcher, S. C.; Hering, J. S.; Niess, R. J. Med. Chem. 2006, 49, 7912-7915. 
16. (a) Zimmermann, K.; Waldmeier, P. C.; Tatton, W. G. Pure Appl. Chem. 1999, 71, 2039-2046; (b) For review, see: Olivera, R.; SanMartin, R.; Churruca, F.; Domínguez, E. Org. Prep. Proced. Int. 2004, 36, 297-330, and references cited therein; (c) Hoyer, H.; Vogel, M. Monatsh. Chem. 1962, 93, 766-774.

17. (a) Harris, T. W.; Smith, H. E.; Mobley, P. L. J. Med. Chem. 1982, 25, 855-858; (b) Nagai Y.; Irie, A. J. Med. Chem. 1982, 25, 1065-1070; (c) Ong, H. H.; Profitt, J. A.; Anderson, V. B.; Spaulding, T. C.; Wilker, J. C.; Geyer III, H. M.; Kruse, H. J. Med. Chem. 1980, 23, 494-501; (d) Manske, R. H. F.; Ledingham, A. E. J. Am. Chem. Soc. 1950, 72, 4797-4799.

18. (a) Lednicer, D. Strategies for Organic Drug Synthesis and Design, Wiley Interscience: New York, 1998, pp 379-400; (b) Li, S.; Chen, H.; Chen, L.; Tsai, J.; Chen, P.; Hsu, S. C.; Wang, E. ARKIVOC 2008, 2, 172-182.

19. Kathryn, R.; Holger, U.S. Patent 042818, 2009.

20. Farrokh, J.; Campos, C.; Hunt, D. A. Tetrahedron Lett. 2015, 56, 5245-5247.

21. (a) Pinder, R. M.; Brogden, R. N.; Speight, T. M.; Avery, G. S. Drugs 1977, 13, 161-218; (b) Midha, K. K.; Hubbard, J. W.; Mckay, G.; Haws, E. M.; Korchinski, E. D.; Gurnsy, T.; Cooper, J. K. Eur. J. Clin. Pharmacol. 1992, 42, 539-544; (c) Constantine, J. W.; Scriabine, A.; Smith, S. G.; McShane, W. K.; Booher, K. D. J. New Drugs 1964, 38, 249-257; (d) Fulton-Kehoe, D.; Rossing, D. M.A.; Rutter, C.; Mandelson, M. T.; Weiss, N. S. Br. J. Cancer 2006, 94, 1071-1078 and papers cited therein.

22. (a) Bloom, B. M.; Tretter, J. R. U.S. Patent 420 851, 1969; (b) Schaumann, W.; Stach, K. Ger. Patent 1232 161, 1961; (c) Stach, K.; Bickelhaupt, F. Monatsh., Chem. 1962, 93, 896-895; (d) Bickelhaupt, F.; Stach, K.; Thiel, M. Monatsh., Chem. 1964, 95, 485-494; (e) Jalander, L.; Oksanen L.; Ahtinen, J. Synth. Commun. 1989, 19, 33493352; (f) Xue, C.; Kung, S. H.; Wu, J. Z.; Luo, F. T. Tetrahedron 2008, 64, 248-254.

23. (a) Rayes, D.; Flamini, M.; Hernando, G.; Bouzat, C. Mol Pharmacol. 2007, 71, 1407-1415; (b) Hernando, G.; Berge, I.; Rayes, D.; Bouzat, C. Mol Pharmacol. 2012, 82, 550-560.

24. Jiang, N.; Li, S. Y.; Xie, S. S.; Yao, H.; Sun, H.; Wang, X. B.; Kong, L. Y. $R S C A d v$. 2014, 4, 63632-63641.

25. (a) Pinto, M. M. M.; Sousa, M. E.; Nascimento, M. S. Curr. Med. Chem. 2005, 12, 2517-2538; (b) Menéndez, C.; Nador, F.; Radivoy, G.; Gerbino, D. C. Org. Lett. 2014, 16, 2846-2849.

26. Verbanac, D.; Jain, S. C.; Jain, N.; Chand, M.; Paljetak, H. Č.; Matijašić, M.; Perić, M.; Stepanić, V.; Saso, L. Bioorg. Med. Chem. 2012, 20, 3180-3185.

27. Shen, Y.; Liu, H.; Chen, Y. J. Org. Chem. 1990, 55, 3961-3962.

28. (a) Aultz, D. E.; Helsley, G. C.; Hoffman, D.; McFadden, A. R.; Lassman, H. B.; Wilker, J. C. J. Med. Chem. 1977, 20, 66-70; (b) Ueno, K.; Kubo, S.; Tagawa, H.; Yoshioka, T.; Osuka, W.; Tsubokawa, M.; Kojima, H.; Kasahara, A. J. Med. Chem. 1976, 19, 941-946.

29. (a) Hamer, R. R. L.; Tegeler, J. T.; Kurtz, E. S.; Allen, R. C.; Bailey, S. C.; Elliott, M. E.; Hellyer, L.; Helsley, G. C.; Przekop P.; Freed, B. S.; White, J.; Martin, L. L. J. Med. Chem. 1996, 39, 246-252; (b) Kumazawa, T.; Ohshima, E.; Harakawa, H.; Sato, H.; Obase, H.; Oiji, Y.; Ishii, A.; Ishii, H.; Ohmori, K. Chem. Phar. Bull. 1991, 39, 27292733.

30. Keiser, J.; Panic, G.; Adelfio, R.; Cowan, N.; Vargas, M.; Scandale, I. Parasites \& Vectors 2016, 9, 376, 1-10.

31. Sleigh, J. N. Biosci. Horizons 2010, 3, 29-39.

32. Perrin, D. D.; Amarego, W. L. F. Purification of Laboratory Chemicals; Pergamon: Oxford, 1988.

33. Naveena, C. S.; Poojary, B.; Arulmoli, T.; Manjunatha, K.; Prabhu, A.; Kumari, N. S. Med. Chem. Res. 2013, 22, 1925-1937.

34. Müller, J.; Limban, C.; Stadelmann, B.; Missir, A. V.; Chirita, I. C.; Chifiriuc, M. C.; Nitulescu, G. M.; Hemphill, A. Parasitol. Int. 2009, 58, 128-135.

35. Fiedler, W.; Neises, B.; Hachtel, J. U.S. Patent 7238 835, 2007.

36. Takizawa, I.; Morita, O.; Oiji, Y.; Hashimoto, T. U.S. Patent 396 550, 1983.

37. Kurokawa M.; Sato, F.; Masuda, Y.; Yoshida, T.; Ochi, Y.; Zushi K.; Fujiwara, I.; Naruto, S.; Uno, H.; Matsumoto, J. Chem. Pharm. Bull. 1991, 39, 2564-2573.

38. Guta, R.; Limban, C.; Missir, A. V.; Caproiu, M. T.; Nuta, D. C. D. Rev. Chim. (Bucharest) 2011, 62, 606-609.

39. Siddegowda, M. S.; Yathirajan, H. S.; Ramakrishna, R. A. Tetrahedron Lett. 2012, 53, 5219-5222.

40. (a) Casarotto, M. G.; Craik, D. J. J. Pharm. Sci. 2001, 90, 713-721; (b) Casarotto, M. G.; Craik, D. J.; Munro, S. L. Magn. Reson. Chem. 1990,
28, 533-540; (c) Wyatt, D. K.; Roscher, N. M.; Grady, L. T. Appl. Spectrosc. 1986, 40, 538-542.

41. Jones, A. K.; Rayes, D.; Al-Diwani, A.; Maynard, T. P.; Jones, R.; Hernando,G.; Buckingham, S. D.; Bouzat, C.; Sattelle, D. B. J. Biol. Chem. 2011, 286, 2550-2558.

\section{Supplementary Material}

Detailed experimental procedures, characterization data, and copies of ${ }^{1} \mathrm{H}$ and ${ }^{13} \mathrm{C}$ NMR spectra of all dibenzo[b,e]oxepinone derivatives prepared. 


\section{Graphical Abstract}

To create your abstract, type over the instructions in the template box below.

Fonts or abstract dimensions should not be changed or altered.

\section{Iron(II) promoted direct synthesis of dibenzo[b,e] oxepin-11(6H)-one derivatives with biological activity. A short synthesis of doxepin}

Jimena Scoccia, ${ }^{a}$ M. Julia Castro, ${ }^{\mathrm{a}, \mathrm{b}}$ M. Belén Faraoni, ${ }^{\mathrm{a}}$ Cecilia Bouzat, ${ }^{\mathrm{b}}$ Víctor S. Martín, ${ }^{\mathrm{c}}$ Darío C. Gerbino ${ }^{\mathrm{a}, *}$ ${ }^{a}$ INQUISUR, Departamento de Química, Universidad Nacional del Sur (UNS)-CONICET, Avenida Alem 1253, 8000 Bahía Blanca, Argentina.

${ }^{b}$ INIBIBB, Departamento de Biología, Bioquímica y Farmacia, Universidad Nacional del Sur (UNS)-CONICET, Camino La Carrindanga km 7, 8000 Bahía Blanca, Argentina.

c IUBO, Departamento de Química Orgánica, Universidad de La Laguna, C/Astrofísico Francisco Sánchez 2, 38206 La Laguna, Tenerife, Spain.

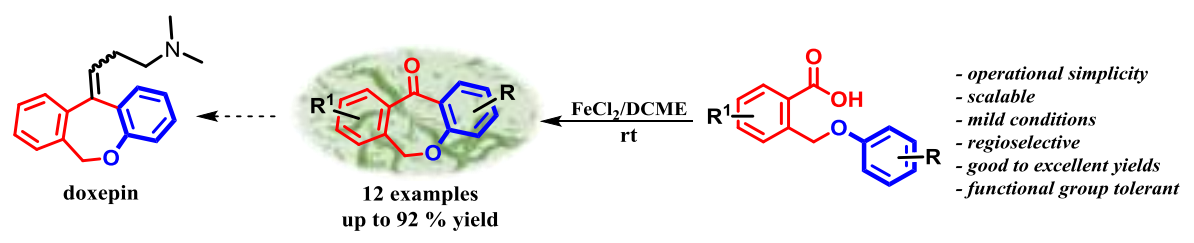

